\title{
SOUTH AFRICAN APARTHEID LEGISLATION II: EXTENSION, ENFORCEMENT AND PERPETUATION*
}

\author{
ELIZABETH S. LANDIS广
}

THE lawyer, who is intimately concerned with the structure of his own society, is by profession fascinated by the mechanics through which a foreign country puts into effect a social philosophy antithetical to that of his own. Therefore, he must be at once disturbed by and curious about the Union of South Africa, which is resolutely attempting to reverse the whole trend of modern civilization towards racial equality.

\section{Extension of Apartheid}

In a previous article ${ }^{1} I$ have described the fundamental structure of apartheid, or racial isolation, in the Union- the society which it affects and the basic statutes which provide its "constitution." In this article I shall attempt to explore the techniques that have been adopted to extend apartheid to every aspect of existence and to enforce and perpetuate the racial separation which is its goal.

\section{Labor}

Apartheid in labor relations differentiates between white and nonwhite in numerous ways, but it affects Africans most disadvantageously. It applies to individual master and servant relationships as well as to collective labor relations.

The restrictions on individual African employees are perhaps one of the most startling aspects of apartheid. The Cape Province Masters and Servants Act of 1856, which is still on the books, ${ }^{2}$ attaches criminal liability to breach of an individual employment contract-as do other provinces' laws which were modeled after it. $^{3}$ The Native Labour Regulation Act ${ }^{4}$ makes it a criminal

*This article constitutes the last of a two-part discussion of apartheid by the author. The first part appeared in an earlier issue of the Yale Laze Journal. Since this article went to print, the Union has become the Republic of South Africa, and the Governor-General has become the State President.

$\dagger$ Member, New York Bar. Co-editor of Liberian Code.

1. Landis, South African Apartheid Legislation $I$ : Fundanental Structure, 71 Y ALE L.J. 1 (1961) [hereinafter cited as Landis].

2. Handbook on Race Relations in South Africa 145 (Hellmann ed. 1949) [hereinafter cited as HANDBOoK].

3. Ibid.

4. Act No. 15 of 1911, as amended by Native Laws Amendment Act, Act No. 54 of 1952 (punishment of a fine of two pounds or imprisonment for two months with or without hard 
offense for an African to desert or absent himself from his place of employment or to fail to enter upon or carry out the terms of his employment contract, to neglect to perform any work or to unfit himself to perform work by use of drugs or alcohol, to refuse to obey any lawful command, or to use any abusive or insulting language toward anyone in authority over him. Although it has been said that the act is applied only to the gold mining industry, it is not a dead letter in everyday situations. ${ }^{6}$ Finally, the still extant Masters and Servants Act of 1880 creates at least 14 offenses with which a servant can be charged, but only one-nonpayment of wages-with which an employer can be charged. ${ }^{7}$

Unions of African workers are denied any official standing by the government. The Industrial Conciliation $\mathrm{Act}^{8}$ the fundamental labor relations law for the white population, defines a "trade union" as "any number of employees in any particular undertaking, industry, trade or occupation ...." But "employee" is defined as "any person (other than a native) employed . . ." ;0 so African trade unions are indirectly excluded from the act's ambit. In addition, Africans are forbidden to represent workers, ${ }^{11}$ and unions are forbidden to appoint Africans as officers. ${ }^{12}$

Benefits of the act are limited to registered trade unions, ${ }^{13}$ and under the predecessor act a union which had any African members was held by the Supreme Court not to be entitled to registration. ${ }^{14}$ African unions nevertheless exist and are admitted to membership in one of the five federations of unions. ${ }^{15}$ Until recently, however, most white unionists have been indifferent or hostile to African workers ; ${ }^{16}$ unionization of Africans generally has been

labor). HANDBoor 145 indicates that the attachment of criminal liability to breach of an employment contract is contrary to South African common law.

5. Commission on the Racial Situation in the Union of South Africa, Report, U.N. GEN. Ass. Off. REc. 8th Sess., Supp. $16 \$ 492$ (A/2505 and A/2505/Add. 1) (1953) [hereinafter cited as 1 U.N. CoMM'N].

6. For example, an 18 year old African girl was recently accused of the criminal offense of leaving her job without giving two weeks notice; counsel argued, unsuccessfully, that the law was outmoded and certainly should not be applied to trivial offenses. 6 AFr. Dig. 145 (1959).

7. 6 AFr. Dig. 145 (1959).

8. Act No. 28 of 1956.

9. Act No. 28 of $1956, \S 1$ (xxrviii).

10. Act No. 28 of $1956, \S 1$ (xi).

11. Act No. 28 of $1956, \S 21$ (5), added by Act No. 41 of $1959, \S 5$.

12. Act No. 28 of 1956, $\S 8(6)$ (e), added by Act No. 41 of $1959, \S 3(\mathrm{~b})$.

13. All provisions of the statute relating to trade unions refer to "registered trade unions." Unions which are not registered may not participate.

14. Sweet Workers Union v. Orkin, [1946] So. Afr. L.R. 303 (C) (applying Industrial Conciliation Act, Act No. 36 of 1937). See HaNdBook 166.

15. The South African Congress of Trade Unions. See generally Hepple, Labour and Labour Lawes in South Africa, Africa South, Oct.-Dec. 1956, p. 28. As of the time the article was written the Congress had 21 constituent unions with 30,000 members.

16. The Labour Party, having its attention focussed on parliamentary action, makes no bid for the support of the disenfranchised Non-Europeans. . . . As regards the 
achieved by African effort, sometimes assisted by white organizers, although a few white unions have established separate unions for Africans in the same industry. ${ }^{17}$

Other nonwhites also suffer from the curtailment of union activity in South Africa. ${ }^{18}$ While mixed unions of white and colored workers already registered under the predecessor Industrial Conciliation Act may continue, ${ }^{19}$ a new amendment requires the establishment of separate branches for white and colored members and prohibits mixed meetings at any level. ${ }^{20}$ The executive body of every mixed union shall be limited to whites only, ${ }^{21}$ and new unions may be registered only if they are "lily white."22 Moreover, any "sufficiently representative" uni-racial group in a mixed union may apply to be recognized as a separate union, taking with it its fair share of the mixed union's treasury ${ }^{23}$ -a provision attacked as threatening the integrity of the whole labor movement. ${ }^{24}$ Between 1956 and 1959 the number of mixed unions fell from 113 to 56 ; the number of uni-racial unions increased from 69 to 121 in the same period.

And, Sir, all this was done voluntarily .... I hope to be able to tell the House in two years' time that there is not a single mixed trade union in the country .... ${ }^{25}$

European workers, their allegiance has been divided between Labour and the capitalist parties, an indication that the main political issues in the country are generally viewed as issues, not between classes, but between European and Non-European, or between Afrikaans-speaking and English-speaking communities....

HANDBOOK $169 ; 1$ U.N. CoMrM?N $\S 432$.

17. HaNDBOok 166; 1 U.N. CoMm's \& 432.

18. Labor M.P.s accuse the Nationalists of being anti-all labor. See, e.g., H.A. DeB., Feb., 1956, col. 817:

There is no intention whatsoever that this [Industrial Conciliation Amendment] Bill should create a strong trade union movement. On the contrary, it may well smash and kill the trade union movement to the detriment of the workers.

19. Act No. 28 of $1956, \S 2(4)$.

20. Act No. 28 of 1956, § \&(3) (a) (i) (aa), (bb), (ii), (iii), as substituted by Act No. 41 of 1959, \& $3(\mathrm{a})$.

Clause 8 compels them [mixed unions], if they want to continue, to apply racial segregation in their procedure. They must have separate branches and hold separate meetings for their White and Coloured members.... [T] he Executive Committee of such mixed trade unions should consist of Whites alone.

H.A. DEB., Jan. 23, 1956, col. 272 (Minister of Labor).

21. Act No. 28 of 1956, $\$ 8$ (3) (a) (i) (cc), superseded by Act No. 41 of 1959, § 3(a).

22. Act No. 28 of $1956, \S 4(6)$.

23. Act No. 28 of 1956, $\S \S 6(1)$ (b), (c), (2). For discussion of the meaning of "sufficiently representative," see H.A. DEB., Jan. 30, 1956, cols. 635-36 (Hepple, Labor M.P.) ; id., Feb. 1, 1956, col. 736.

24. H.A. DEB., Feb. 1, 1956, col. 739.

25. H.A. DeB., April 20, 1959, col. 4248. But an opposition member had pointed out that there were only 70,427 colored and Indian trade union members in December, 1948, as compared with 330,324 white members. H.A. DEB., Feb. 1, 1956, col. 741. 
Since breach of an individual labor contract by an African is a crime, it is not surprising that it is unlawful for Africans to strike. ${ }^{28}$ Under the Native Labour (Settlement of Disputes) Act, which governs African labor relations, the penalty is $£ 500$ or three years' imprisonment or both. ${ }^{27}$ To ensure that no collective action escapes this ban, this act includes in the definition of strike any of the following conduct when committed by any body or number of employees of the same or different employers: refusal to continue work, to accept reemployment, or to comply with terms or conditions of work; obstruction of work; or breach or termination of any employment contracts; provided that such conduct is committed in pursuance of any combination, agreement, or understanding and that the purpose is to compel any employer to agree to terms or conditions of employment, to refrain from changing terms, to reinstate terms of employment for the striking employees or any others, or to employ or to terminate the employment of any person. ${ }^{28}$ Whenever a person is charged with instigation or incitement to strike and any prohibited conduct is proved, the act raises a presumption, until the contrary is proven, that such conduct was in pursuance of a combination, agreement, or understanding and for a purpose stated in the charge. ${ }^{29}$ The effectiveness of this policy is demonstrated by the fact that there were only thirtythree work stoppages in 1955 (even before the cited rigorous definition of strike was enacted) among $6,400,000$ Africans working in the Union. ${ }^{30}$ Wages losses from strikes dropped from $£ 1,810,000$ in 1947 to $£ 40,000$ in 1953.31

In addition to prohibiting strikes, the Settlement of Disputes Act provides for the establishment of a Central Native Labour Board, comprised of whites, to advise the Minister, ${ }^{32}$ and permits the establishment of regional native labor committees of three or more Africans in addition to a (white) Native Labour Officer as chairman, which have general liaison and informational functions. $^{33}$ Africans in establishments with twenty or more African employees

26. Native Labour (Settlement of Disputes) Act, Act No. 48 of $1953, \S 18(1)$, superseded by Act No. 59 of $1955, \S 1$. Lock-outs by employers are also made illegal by this section. See, e.g., N.Y. Times, Feb. 2, 1960, p. 6, col. 4.

For prohibition of certain strikes by workers of any color, see text at notes 303-06 infra.

27. Act No. 48 of 1953, $\$ 18$ (2), superseded by Act No. 59 of $1955, \S 1$.

28. Act No. 48 of 1953, § 18(5), superseded by Act No. 59 of 1955, $\S 1$. The former definition was not considered sufficiently inclusive. SEN. DEB., June 20, 1955, cols. 4430-31 (Minister of Labor).

29. Act No. 48 of $1953, \S 18(3)$, superseded by Act No. 59 of $1955, \S 1$.

30. Sen. DeB., June 20,1955 , cols. 4431, 4447. Of these 33 work stoppages, only 11 resulted in prosecution under the statute.

31. H.A. DeB., Feb. 1, 1956, col. 825. Labor Member Hepple noted that there were 73 illegal strikes by Africans in 1955, in 15 of which the workers gained higher wages or better working conditions. Hepple, Labour and Labour Laws in South Africa, Africa South, Oct.-Dec. 1956, p. 31.

32. Act No. 48 of $1953, \S 3$.

33. Act No. 48 of $1953, \S \S 4,6$. 
may, under the direction of a native labor officer, elect a works committee of three to five members. ${ }^{34}$

Whenever an industrial council (established under the Industrial Conciliation Act for non-African workers) proposes to determine working conditions for an industry, trade, occupation, or establishment in which Africans also work, the Central Native Labour Board and the appropriate regional committees shall be notified and may send a representative to represent them but not to vote; when the industrial council reaches its decision, the chairman of the Central Board shall inform the Minister whether the Board agrees with the Council's decision or whether recommendations as to Africans' wages shall be obtained from the Wage Board. ${ }^{35}$

The act also provides for the appointment of (white) Native Labour Officers in each area to keep track of labor relations locally and head off pending labor disputes. ${ }^{36}$ Labor disputes which cannot be settled by a Labour Officer or the Central Board are sent to the Wage Board for its recommendations as to conditions of employment. ${ }^{37}$ Recommendations approved by the Minister are published in the Government Gazette (which contains all official notices and proclamations), and it is an offense to refuse to accept such terms. ${ }^{38}$

The wages and hours of Africans who are not engaged in domestic, government, or farm work, or in work to which terms of employment have been extended under the Industrial Conciliation Act, are determined under the Wage Act of $1957 . .^{30}$ It provides for the establishment of a (white) Wage Board.40 The Board, or a division thereof, makes investigations upon request of the Minister and recommends minimum wages, piece rates, and related matters; after opportunity to make representations the Minister may make a conclusive determination of wages for the industry, area, or trade involved. ${ }^{41}$ The Minister may also modify, cancel, or extend the application of this determination and grant exemptions. ${ }^{42}$

34. Act No. 48 of $1953, \S 7$.

35. Act No. 48 of $1953, \S 9$.

36. Act No. 48 of $1953, \S 8$.

37. Act No. 48 of 1953, $\S \S 10,11$. A labor dispute is defined as a dispute between an employer or employers and two or more employees relating to employment, conditions of employment, or refusal to re-employ any African, but does not include a dispute as to an interpretation of law or a dispute during the duration of any order or award applicable to the disputants which contains provisions for dealing with the disputed question. Act No. 48 of $1953, \S 1(\mathrm{v})$.

38. Act No. 48 of 1953, $\$ 15(1)$.

39. Act No. 5 of 1957, $\$ \S 8(1), 14$. Brady points out that the bulk of African labor is in agriculture and domestic service. Brady, Democracy IN tHe Dominions 441 (1952) [hereinafter cited as BRADY]. This, of course, excludes Africans in the mines.

40. Act No. 5 of 1957, $\S \S 3(1)$, (4), (11). The Board is to have three members, with more added as needed.

41. Act No. 5 of $1957, \S \S 8(1), 13,14$.

42. Act No. 5 of 1957, $§ \S 15,16,17,19(1)$. 
Since these statutes give Africans very little to say about their working conditions except in an advisory capacity, the social results are exactly what might be expected :

The average earnings of Non-Europeans in most occupations, even including the lower grades of teaching, are insufficient to support a family and fall below the Poverty Datum Line ....43

Africans suffer equally in relation to other working conditions. Recently a new amendment 44 to the Factories Act quietly excised the proviso prohibiting racial discrimination from the section which sets out health and safety standards previously applicable to all workers regardless of race. ${ }^{45} \mathrm{Now}$, for example,

[T] he clothing equipment in cases of fire, risk or heat can be different for a White man and a Black man. The asbestos suiting before a smoking furnace can be different in quality. . . .46

Even in an area where many racists tend to make a sentimental exception, the South African government is not to be deflected from its course. Under the same amendment it is considering banning

the joint attendance of ... [white and nonwhite] workers at functions such as Christmas parties .... In many cases the ... workers contribute during the year to those Christmas parties and then all the children receive presents. It has now become apparent these Christmas parties al-

43. HANDво0к 144, 309, 345. Nor have these conditions changed substantially. Average wages and salaries for 1958 were reported as follows:

\begin{tabular}{lcc}
\hline \hline & mining industry & $\begin{array}{l}\text { manufacturing, } \\
\text { including private } \\
\text { construction }\end{array}$ \\
\hline whites & $£ 1,095$ & $£ 868$ \\
coloreds and & 236 & 282 \\
Asians & $68^{*}$ & 156 \\
Africans & & \\
\hline
\end{tabular}

*Add free board and lodging for the worker but not for his family.

\section{H.A. DeB., Jan. 29, 1960, cols. 598-99.}

See also Brookes \& Macaulay, Civil Liberty in South Africa 99 (1958) [hereinafter cited as Brookes \& Macaulay] ; 2 U.N. Comm'n \$ 214 ; H.A. Deb., April 21, 1959, col. 4316. Mrs. Ballinger was quoted in 1958 as saying that the average earnings of an African in industry was $\$ 13$ per month, and the minimum required for economic existence was $\$ 23$. 6 Afr. Dig. 63 (1958). See generally Gillman, Malmutrition in African Condition, in Africa in Transitron 11 (Smith ed.); and Blumberg, Durban Explodes, Africa South, Oct.-Dec. 1959, pp. 9, 11. 21(d).

44. Factories, Machinery and Building Work Amendment Act, Act No. 31 of 1960, §

45. Factories, Machinery and Building Work Act, Act No. 22 of 1941, 5 51(3) ; H.A. Deb., Jan. 27, 1960, col. 512; SEN. Deb., March 14, 1960, col. 800.

46. Sen. DeB., March 14, 1960, col. 801 ; id., cols. 798-99. 
low all their workers, European and non-European, to mingle together in the hall and to mix socially on the same occasion. ${ }^{47}$

Of all industrial workers the African mineworkers are perhaps the most unfortunate. Their work is harder and more unhealthy than most, their working conditions more severe, and their isolation in barracks, for periods of a year or more, not only from their families but from all normal human contact, is exceptionally galling. ${ }^{48}$ In addition, there are constant invidious comparisons with the working conditions of white mineworkers :

European workers got a great many improvements in their conditions of employment during the war, none of which went to the African mineworkers. They got extended holidays with pay, they got benefit societies, and ... a cost-of-living allowance which the Native mineworkers never got, while the cost of living was rising. Every other section of the industrial field got a statutory cost-of-living allowance, but the African mineworkers did not get it. ${ }^{49}$

Finally, while weekly or monthly paid white miners profit by the declaration of additional public holidays, ${ }^{50}$ the Africans lose pay. They are paid by the shift and receive neither regular pay for holidays not worked nor overtime for holidays worked. ${ }^{51}$

Yet even the most unfortunate African miner is better off than any but an exceptional farm worker. While white domestic servants on farms are paid average wages about five times those paid to Africans, a differential not too much at variance with that in industry, white farm workers average 12-15 times the average wage of African farm workers; $; 2$ and the conditions of African agricultural labor are in all other respects so appalling that Africans seek any other work in preference and white farmers are forced to seek prison labor to supplement their regular hands. ${ }^{53}$

47. Id., cols. 599-600 (Deputy Minister of Labour).

48. The entire labour organization in the Rand mines is based on the principle and practice of separation from the family; the men go off to work in the "golden city" while the women and children look after the fields and cattle in the Reserves.

[T] his system ... has resulted in the semi-abandonment of the cultivable land in the reserves and the creation, in the hostels of the Johannesburg outskirts of conditions under which homosexuality and other perversions wreak havoc. . . How far this separation of married couples is responsible for the Bantus' dislike for mine work cannot be said exactly; but it is probably an important factor in the preference shown by available Native labour for the secondary industries. ...

1.U.N. COMIM'N § 773.

49. H.A. DEB., April 16, 1959, col. 3636 (Mrs. Ballinger, African representative).

50. See, e.g., Mines and Works Amendment Act, Act No. 51 of 1959, adding Ascension Day and Day of the Covenant to the two recognized public holidays.

51. H.A. Deb., April 16, 1956, cols. 3634-35.

52. Statistics issued by the Bureau of Farming and Statistics for 1956, cited in 6 AFr. DrG. 148 (1959); see 2 U.N. CoMN'N \$\$ 211, 214.

For conditions on farms, see, e.g., 6 AFr. DIG. 236 (1959) ; Fairbairn, The Newe Serfdom, Africa South, Oct.-Dec. 1959, p. 34; First, Bethel Case-Book, Africa South, April-June 1958, p. 14; Turok, The African ont the Farm, Africa South, Oct.-Dec. 1959, p. 28.

53. See text at notes 181-82 inffra. 
Since African workers lack the franchise, ${ }^{54}$ they come out as badly in relation to social welfare legislation as they do in relation to wages and working conditions. Compared to white (and even to other nonwhite) workers, their benefits, if any, are lower and subject to different conditions. Thus the Workmen's Compensation Act excludes from its benefits nearly all domestic servants, agricultural employees, and diggers of carborundum and alluvial gold and diamonds ${ }^{55}$-in other words, the majority of employed Africans. The Unemployment Insurance Act excludes most Africans employed in gold or coal mines, in rural areas, or in domestic households. ${ }^{\varpi 6}$ In 1953 the UN Commission on the Racial Situation in South Africa stated that social welfare expenditures appear to be in the proportion of three for whites, two for coloreds, and one for Africans, ${ }^{57}$ and there are many instances in which the discrepancies are even greater. ${ }^{58}$

The last, and possibly the most serious, handicap to nonwhite, particularly African, laborers is "job reservation." Such job reservation arises in the first instance out of the general circumstances of segregated life, which "naturally" produce a high correlation between race and occupation. ${ }^{50}$ Thus the professions, except religious service and teaching, are almost entirely closed to non-Europeans due to lack of education, funds, and facilities for them, as well as to social prejudice and an insufficient paying clientele. ${ }^{60}$ Similarly, the Apprenticeship Act ${ }^{61}$ effectually prevents most non-Europeans from be-

54. See text at notes 219-31 infra.

55. Act No. 30 of $1941, \S \S 3(2)(\mathrm{f}),(\mathrm{g}),(\mathrm{j})$.

56. Act No. 53 of 1946, $\$ \$ 2(2)$ (b), (c), (i) ; Brookes \& MaCaUlay 107.

57. 1 U.N. COMM'N $\$ 791$.

58. Thus the Pneumoconiosis [Dusty Diseases] Act, Act No. 57 of 1956, provides the following benefits for the same conditions:

\begin{tabular}{|c|c|c|c|c|c|}
\hline Recipient & Lump stm & (or) & Worker & $\begin{array}{c}\text { Monthly payments } \\
\text { Dep.Wife }\end{array}$ & $\begin{array}{c}\text { (each) } \\
\text { Dep.Children }\end{array}$ \\
\hline White & $£ 480-750$ & & $£ 12-25$ & $£ 3-6.10$ & $£ 1.10-4.10$ \\
\hline Colored & $175-250$ & & $4-10$ & $1-3$ & $.10-1.10$ \\
\hline African & $125-240$ & & \multicolumn{3}{|c|}{$\begin{array}{l}\text { (no alternative, but lump sum paid to Native Affairs } \\
\text { authority which may pay it over to him in a lump sum } \\
\text { or in monthly installments or may pay it over to } \\
\text { another for his benefit or that of his dependents.) }\end{array}$} \\
\hline
\end{tabular}

$I d ., \S \S 75,77,83,84,87,90,92$. Death benefits are comparable. $I d ., \S \S 78,79,80,81,82,85$, 86,91 .

The Pension Laws Amendment Act, Act No. 61 of 1960, § 15(1), provides bonuses to certain pension recipients which range from $£ 24$ per year to whites to $£ 6$ to Indians or colored and $£ 1.10$ to Africans.

59. HANDBOOK 109-10; BRAdY 442; 1 U.N. CoNMM'N $\$ \$ 770,775,776$. Africans do only menial, manual labor (always the worst paid in any country); Indians and colored fall somewhere in between Africans and whites in the occupational hierarchy and as to pay scales.

60. HANDBOOK 123-24.

61. Act No. 37 of 1944. 
coming artisans: the educational requirements of the act are too high, and the facilities required for technical training exist in relatively few communities. Moreover, many employers don't want non-European apprentices, and many non-European employers don't have approved facilities. ${ }^{62}$ Finally, the traditional prohibition against discrimination on the basis of race in setting wage rates and the high rates set in many industries discourage employers from hiring Africans except when muscular exertion is the chief job requirement. ${ }^{63}$

Aside from these problems inherent in segregated life, there are many statutory provisions under which certain jobs may be reserved for a particular race. While job reservation is traditional in mining, where Africans do manual labor only, ${ }^{64}$ the real forerunner of large-scale statutory job reservation appears to be the Native Building Workers Act of $1951 .^{65}$ The statute provides that no persons in an urban area shall employ any African to do any skilled building work and that no African shall perform any skilled work in an urban area. ${ }^{60}$ Violation of these prohibitions is a crime. ${ }^{67}$ In explaining the 1955 amendments to this statute, the Minister of Labor candidly announced that:

If this Bill is passed, it will impose a total prohibition throughout the country for any Native to do any skilled work in any European area.... [T] his is the sphere of the European, and his work should be reserved for him. When he is not able to do it himself, he obtains additional labour from the non-European circles to do it for him. Then the work would only be done by virtue of the fact that they have been granted exemption, but they cannot regard it as their right and they cannot rely on it that it would always be theirs .... ${ }^{68}$

62. HaNdBook 151-52.

63. BRAdY 441-42.

64. H.A. Deb., Jan. 30, 1956, cols. 628-29; International Comm' $N$ of JuRists,

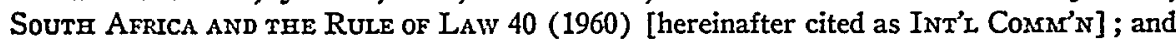
see Mines and Works Act, Act No. 27 of 1956, $\$ 12(2)$ (a), empowering the GovernorGeneral to reserve certain jobs for Europeans and coloreds.

65. Act No. 27 of 1951 . But Handoooz 152 points out that since 1946 "certain unskilled posts, notably in the government service, have been reserved for Europeans ...."

66. Except in a native area or upon a building and premises owned by him or intended for his own or his dependents' occupation. Act No. 27 of 1951, § 15(1), superseded by Act No. 60 of $1955, \S 2$.

Section 16(1) of the Act allows the Governor-General to restrict European skilled workers from working in native areas under certain conditions. "Urban Area" was redefined by Native Building Workers Amendment Act, Act No. 56 of 1959, § 1, substituting a new definition in $\S 1$ of the principal act; it is the same as an urban area as defined in the Urban Areas Act, and includes:

any area where development has taken or is taking place which in the opinion of the Minister has resulted or is likely to result in considerable building activity, and which he has by notice in the Gazette declared to be an urban area for the purposes of this Act....

67. Act No. 27 of 1951, § 15(3), superseded by Act No. 60 of $1955, \S 2$.

68. Sen. DeB., June 20, 1955, cols. 4464, 4465-66; id., March 20, 1960, col. 1562. 
He added that the new provisions would apply to individual houseowners, flat dwellers, or factory managers who did work without hiring a contractor. $\mathrm{He}$ stated, however, that carrying mortar or bricks is not a part of brick-laying but a separate unskilled occupation, thereby implying that employment of Africans as brick-carriers is not within the act's prohibition. ${ }^{69}$

The act also requires the registration of all African building workers and learners and makes it an offense to refuse to produce a certificate of registration. ${ }^{70}$ Africans may become registered as skilled workers by passing certain tests or a learners' course prescribed by the Minister ${ }^{71}$ but the number eligible for training is to be limited, and an employer who engages such learners may employ them in African areas only and may employ whites there only as supervisors or instructors. ${ }^{2}$ Four years after the act was passed there were 246 learners in training and 1,546 Africans had applied to take tests; 1,000 had completed them and 545 had been granted certificates without tests. $^{73}$

Provision for job reservation has since been made general. ${ }^{74}$ The Minister is empowered to reserve all or any part of any kind of work, and the "extent to which persons of any race (i) are ... employed or available for employment; or (ii) are likely to become available for such employment" need not affect the Minister's directive. ${ }^{75}$ By this means, the law will

safeguard the standards of living of the White workers of South Africa and.. ensure that they .... will not be exploited by the lower standards of living of any other race. ${ }^{76}$

The basis for this fear was set out in the Botha Report, which showed that

European workers have already been ousted from a series of trade [sic] which they will never regain ... from the distribution industry as motor vehicle drivers; ... the building trade in the Cape; ... from the baking industry, from the leather industry, from the plate metal industry, from the manufacture of light electrical equipment, from the hat manufacturing industry, etc. This process is still going on ... . ${ }^{77}$

The natural inference from this report, that nonwhites endanger the employment opportunities of whites, has been disputed. The ratio of whites employed to nonwhites has remained 3 to 7 for many years, except during the depression when the proportion of whites employed rose sharply; the ratio of whites' earnings to nonwhites' earnings has remained 4 to 1 over a long period; in the

69. Id., June 20, 1955, col. 4496. It should be noted that Act No. 60 of 1955, § 2(2), which substituted $\S 15(2)$ of Act No. 27 of 1951, specifically excludes skilled work done on farms exclusively for farming purposes.

70. Act No. 27 of 1951, $\$ \S 11(1)$, (4).

71. Act No. 27 of 1951, § 11(2).

72. Act No. 27 of $1951, \S \S 10(2), 14(1)(b)$.

73. Sen. Deb., June 20, 1955, col. 4463.

74. Act No. 28 of 1956, §77, superseded by Act No. 41 of 1959, $\$ 14$.

75. Act No. 28 of $1956, \S \S 77$ (6) (a), (6) (b), (7) (a).

76. H.A. DeB., Jan. 23, 1956, col. 276.

77. Id., col. 269. See N.Y. Times, May 8, 1961, p. 45, col.7. 
'50's, when the number of nonwhites employed in manufacturing increased sharply, almost every industry suffered a shortage of white workers, who enjoyed full employment. ${ }^{78}$

In any case, the effect of the statute has been felt sporadically throughout the Union. In Durban nonwhites may not be employed as municipal refuse truck drivers for five years. ${ }^{79}$ In Capetown no more colored may be hired as traffic policemen, ambulance drivers, or firemen. ${ }^{80}$ Nonwhites employed in the clothing industry work in fear of the reimposition of regulations reserving a large part of the work for whites which were retracted for economic reasons. ${ }^{81}$

In addition to these straightforward methods of job reservation, the opposition has accused the government of trying to extend it via the backdoor by a recent amendment to the Factories Act ${ }^{82}$ which extends the power of the Minister of Labor to prescribe segregated facilities in industrial and manufacturing plants and shops. ${ }^{83}$ Previously, equality of treatment was required by law ${ }^{84}$ except in the "social aspects," segregated restrooms and eating facilities being the traditional exceptions. ${ }^{85}$ Under the new amendment, regulations are envisaged requiring separate exits and entrances, separate timeclocks, separate pay offices, separate first-aid rooms, and separate eating utensils. ${ }^{80}$

\section{Nursing}

Apartheid is also being applied increasingly to nursing, although discrimination has long existed as a matter of practice. In 1957 salary scales for African

78. H.A. DeR, April 20, 1959, cols. 4253-4254. See generally Hepple, Unemployment by Race, Africa South, Jan.-March 1960, p. 48; Hepple, The Fiery Cross of Job Reservation, Africa South, April-June 1958, p. 42.

As a consequence of the shortage of white workers, the Union government is seeking white immigrants. N.Y. Times, April 13, 1960, p. 1, col. 2; id., May 8, 1961, p. 45, col. 7.

79. 6 AFr. Dig. 28 (1958).

80. Id. at 147 (1959) ; N.Y. Times, April 24, 1959, p. 3, col. 6.

81. Brookes \& Macaulay $98 ;$ N.Y. Times, April 24,1959, p. 3 , col. 6.

S2. H.A. DEB., Jan. 27, 1960, col. 500 (construing Act No. 31 of 1960, amending Act No. 22 of 1941).

83. Act No. 31 of $1960, \S 21$ (a), amending $\S 51(1)$ (b) in principal act; Act No. 31 of 1960, $\S 21$ (b), adding $\S 51(1)$ (h) bis. H.A. Deb., Jan. 26, 1960, col. 453; Sen. Deb., March 9, 1960, col. 618 .

84. Act No. 22 of 1941, § 51(3), deleted by Act No. 31 of 1960, § 21 (d).

85. SEN. DeB., March 14, 1960, cols. 793, 800.

86. H.A. DEB., Jan. 28, 1960, cols. 554-55 (Deputy Minister of Labour). Some of the flavor of these remarks may be gained from the following excerpt:

If in the afternoons White workers have to rub shoulders with non-Whites in their rush to get out, then surely that is the very thing that disturbs race relations. They may work together harmoniously the whole day during working hours. The Natives or the Coloured assist the White man, carries [sic] his tools for him, and everything goes well. But if they rush out together in the afternoon and bump one another we can understand that it disturbs race relations....

Id., col. 554. See SEN. DeB., March 9, 1960, col. 598. 
nurses were only $50 \%$ of those recommended in 1944, and nonwhites received less annual leave than white nurses and generally had fewer privileges. ${ }^{87}$ In addition, training was unavailable in fever nursing, mental nursing, mothercraft, orthopedic nursing, and theater technique; and there were only two full-time schools of public health nursing open to nonwhites. ${ }^{88}$ However, these shortcomings were somewhat mitigated by the fact that nonwhite nurses had some voice in the Nursing Association, which controlled professional training and standards. ${ }^{89}$ Indeed, an incident in 1944, in which nonwhite nurses of the Witwatersrand branch of the Association elected seven out of 12 candidates for the local executive board although nonwhites constituted less than half the registered nurses in the branch, ${ }^{90}$ was resurrected to justify the Nursing Act of $1957 .{ }^{91}$ A poll of the country's nurses showed a slight majority in favor of segregation in the Nursing Association and Council, and the Council by a single vote-cast by its president-also backed separation by race. ${ }^{22}$ With this professional approval the Nationalists introduced the legislation which would ensure that "we will have our White nurses who will nurse the White patients, and . . non-White nurses for the non-White patients ...."283

To this end, the act creates a South African Nursing Council composed of technical members named by the government and other members elected by geographical units of nurses, midwives, male nurses, student nurses, and the advisory boards for colored and African nurses. ${ }^{94}$ All members, even those who represent colored and African nurses, are to be white South Africans permanently resident in the Union. ${ }^{95}$ Control of the profession, including schools, examinations, complaints and charges, is vested in the Council, which has the duty of registering all nurses in separate registers for whites, coloreds, and Africans. ${ }^{96}$ The act creates an advisory board for colored nurses and another for African nurses, each composed of elected members of the race concerned. ${ }^{97}$ The South African Nursing Association is also created to provide efficient nursing service and promote the interests of the profession. ${ }^{\text {. }}$ The control of the Association is vested in a board chosen in the same manner as

87. SEN. DeB., June 12, 1957, col. 7896.

88. Id., col. 7898 .

89. Id., cols. 7937-39.

90. H.A. DeB., June 11, 1957, col. 7930. In 1957 there were about 3,000 nonwhite nurses out of a total of about 8,000 registered nurses; in 1944, when the incident occurred, there were only 841 nonwhites nurses.

91. Act No. 69 of 1957.

92. H.A. DeB., June 11, 1957, col. 7845.

93. Id., col. 7850 .

94. Act No. 69 of 1957, § 3(2).

95. Act No. 69 of $1957, \S 4(1)$ (c).

96. Act No. 69 of 1957, $\S 10,12,14,15$.

97. Act No. 69 of 1957, $\$ \$ 16,17$.

98. Act No. 69 of 1957, Pt. IV. Members include all nurses, student nurses, midwives, and similar persons. 
the nursing members of the Nursing Council.99 Separate meetings of each "class" (race) are required, and decisions of the colored or African sections are to be conveyed by the colored or African advisory committees, together with recommendations, to the governing board. ${ }^{100}$ Finally, the statute provides for the implementation of apartheid in the actual conduct of nursing:

Any person who, except in cases of emergency, causes or permits any white person who is registered or enrolled ... to be employed under the control or supervision of any ... nonwhite person, in any hospital or similar institution or in any training school, shall be guilty of an offence....101

Summarizing the act's social objectives, one commentator has remarked :

$[I] n$ the Nursing Council and ... Association the control will be in the hands of the White nurses .... [I]t will prevent social integration and equality in the profession ... [and will ensure that no] non-White ... [will sit] in judgment over a White person..$^{102}$

Even before the act became law, it was clear that it would be used to discriminate further between the training of white and nonwhite nurses. ${ }^{103}$ Soon after the act became effective African nurses were directed to register their identity numbers, a requirement which could be fulfilled only by obtaining a "reference book" (the hated identity pass which African women were for the first time being required to carry). ${ }^{104}$ Even when this regulation was temporarily suspended due to their protests, the nurses had to state their "racial group" (i.e., tribe), the supervisors refusing to accept the designation "African," which the nurses preferred. ${ }^{105}$ Identity numbers were soon required again, ${ }^{106}$ but the Nursing Council gave up differential training when it was warned that the simpler training for nonwhites might make all South African nursing certificates invalid internationally. ${ }^{107}$

99. Act No. 69 of $1957, \S 35$.

100. Act No. 69 of 1957, §§ 33(1), (5).

101. Act No. 69 of 1957, § 49 .

102. H.A. DEB., June 12, 1957, cols. 7851, 7853.

103. Taking the practical circumstances into account, and in order to give the non-White nurses a training which will fit in with their own people, it is necessary to have certain differences without lowering the standards. In the first place it is unrealistic to have precisely the same dietary courses for Whites and for non-Whites....

In the second plaçe a distinction should be made in regard to the civilizing aspect of the training, because a larger part of the training of the non-White must be devoted to the civilizing aspect, to the anthropological aspect and to the aspect of patient psychology....

H.A. DEB., June 11, 1957, cols. 7870-71.

104. Gell, Nursing Apartheid: A Slight Retreat, The Forum, July 1958, p. 18; see

Gov't Notice No. 2009, So. Afr. Gazette, Dec. 27, 1957. See text at notes 183-89 infra.

105. Gell, supra note 104, at 18.

106. Gov't Notice No. 1128, So. Afr. Gazette, August 8, 1958, p. 36. For a sequel, see N.Y. Times, March 19, 1959, p. 8, col. 4.

107. Gell, supra note 104, at 19, citing Lancet (British medical journal), June 7, 1957.

And for evidence of another form of discrimination between white and nonwhite nurses, see 


\section{The Other Professions}

Discrimination is not, of course, limited to the kinds of work discussed above. It affects nonwhites in every walk of life, including the handful who have been able to enter the professions. Thus an African advocate has been denied the right to have his chambers with his colleagues in Johannesburg. ${ }^{10 s}$ In Capetown the first African advocate admitted to the South African Supreme Court was compelled by the Group Areas Act to leave his chambers and move to an area reserved for Africans-thereby disqualifying him from practice in the city since court rules require advocates to have chambers within three miles of the Supreme Court building. ${ }^{109}$ An Indian advocate in Natal has been assigned to a separate robing room, but he still enters by the same door as white advocates and sits at the bar with his European colleagues. ${ }^{110}$

\section{Public Institutions and Facilities}

Segregation in public institutions and facilities has long existed by custom and local law. ${ }^{111}$ But it was only in 1953 that the national legislature enacted a general statute in the field, the Reservation of Separate Amenities Act. ${ }^{112}$

This act represented the final victory by Parliament in a prolonged dialogue with the courts. In a series of cases the courts had shown a predilection, indeed nearly a genius, for reading a "separate but equal" requirement into measures which on their face authorized separate and unequal facilities. 113 The frustrated legislators finally managed to make their intentions explicit ${ }^{114}$

Gov't Notice No. 1132, So. Afr. Gazette, July 24, 1959, pp. 16-18, setting up schedules of travel and other allowances for members of the Nursing Council and Advisory Boards.

108. BRoOKES \& MaCaULAY 46.

109. 6 Afr. Dig. 66 (1958).

110. BRookes \& MACAULAY 46.

111. Carter, The Politics of Inequality 96 (1958) [hereinafter cited as Carter]; see, e.g., Prisons Act, Act No. 8 of 1959, $\$ 23(1)$ (b). In Minister of Posts \& Telegraphs v. Rasool, [1934] So. Afr. L.R. 167 (AD), segregation in post offices was held to be legally extended to Indians despite the polite regrets of the Appellate Division.

112. Act No. 49 of 1953.

113. [T] he problems for the court are accentuated ... by the technical consideration that the South African constitution (apart from the entrenched clauses) is lacking in any bill of rights upon which courts of law might rely to implement their policy preferences and is lacking even in any generally accepted power of judicial review. It is more striking, therefore, that the Supreme Court has been able to introduce (necessarily as the product of considerable mental and verbal ingenuity in view of the absence of any bill of rights provisions) the principle of "separate but equal," this, be it noted, without any reference to American constitutional law practice.

McWhinney, Race Relations and the Courts in the Union of South Africa, 32 CAN. B. REv. 44, 71 (1954) ; CARTER 97. The leading cases are Rex v. Lusu, [1953] 2 So. Afr. L.R. 484 (AD); R. v. Abdurahman, [1950] 3 So. Afr. L.R. 136 (AD), apparently overruling George v. Pretoria Municipality, [1916] So. Afr. L.R. 501 (T) ; R. v. Carelse, [1943] So. Afr. L.R. 242 (C) (bathing beaches). But see R. v. Sesidi, [1953] 4 So. Afr. L.R. 634 (GW).

114. [I]n that Act provision was made for the reservation of public premises for the exclusive use of persons of a particular race or colour, and it is not a requirement that 
in 1953 by specifically permitting private as well as public authorities in charge of public premises (excluding streets) or vehicles to reserve such premises or vehicles or any portion thereof for the exclusive use of persons belonging to a particular race or class

[even if no such premises or portion] has similarly been set apart, demarcated or reserved for the exclusive use of persons belonging to any other race or class ... [ [or if any other portion or premises set aside or reserved for another race or class] is not substantially similar to or of the same character, standard, extent or quality as the premises ... [etc., set aside for the preferred race or class]. ${ }^{115}$

But even this broad language, it appears, did not cover beaches and swimming pools below the high water mark, where nonwhites could "intrude" from the water side $;^{110}$ an amendment has now corrected this oversight. ${ }^{117}$

Allied to and arising out of the segregation of nonwhites in public facilities

at the same time a similar place should be set aside for the use of any other race or colour, and if some premises are indeed set aside for the use of persons of another class or race, they need not necessarily be of the same nature, standard, scope or grade as the other premises....

SEN. DeB., March 14, 1960, cols. 786-87 (Minister of Lands). H.A. DeB., Jan. 28, 1960, col. 521 ("The 1953 Separate Amenities Act arose, in effect, out of the Lusu judgment ... .")

115. Act No. 49 of 1953, § 3. Section 2(2) makes it an offense for a person of one race wilfully to enter public premises or a public vehicle set aside for members of another race.

The statute presumably would cover crematoria, in which a Tranvaal ordinance of 1939 authorized the setting aside of separate sections for white persons, persons of different religions, Africans, Asians and "66 other coloured persons." Local Gov't Ordinance, amended by Ordinance No. 12 (1941), cited in 25 J. CoMr. Leg. \& INT'i L. (3d ser.) Pt. 1,168 (1943).

Similar provisions specifically relating to railways and buses are found in : Railways and Harbours Control and Management (Consolidation) Act, Act No. 70 of 1957, §§ 3(1)(f) (ii), 6(2), 7(1) ; and Motor Carrier Transportation Amendment Act, Act No. 44 of 1955, \& 14, amending Act No. 39 of 1930, $\$ 15$ bis, added by Act No. 50 of 1949, § 4. that

116. SEN. Deb., March 14, 1960, col. 787. But a member of the opposition pointed out

[T] he public of all races have in the past enjoyed common rights on our beaches since time immemorial. The old Roman-Dutch writers ... have described our beaches as being "Res commmunes"-as belonging to all mankind. I would now ask ... for an assurance that ... he [the Minister] will insert a condition under section 4 of the Seashore Act to the effect that adequate facilities ... will be provided for the various racial groups....

H.A. DEB., January 28, 1960, col. 525.

And the following colloquy took place between the government representative and an opposition member advocating equality of treatment:

Do you want the same sharks on the European side as on the Coloured side?

We certainly would wish, if we could, to arrange a distribution of sharks which is not manifestly inequitable or capricious. ld., col. 523.

117. Reservation of Separate Amenities Amendment Act, Act No. 10 of 1960. 
is the restriction of their cultural and intellectual life. ${ }^{118}$ While local practices vary, even the most fortunate nonwhites share few opportunities which Europeans take for granted. ${ }^{119}$ Apartheid applies to libraries, zoos, recreational facilities, the letting of municipal halls, even to the press gallery in the city council chamber in Johannesburg; and it often deprives nonwhites of even a single chance to see foreign theatricals when they come to the Union. ${ }^{120}$ The new definition of "occupation" in the Group Areas Act and the restrictions on nonwhite institutions in the Urban Areas Act will further restrict the cultural possibilities for nonwhites. ${ }^{121}$

\section{Religion}

Apartheid had been extended to religion, as well as to the other non-material aspects of life in the Union. Africans may now be prohibited from attending church in white areas. ${ }^{122}$ The government originally intended to place on the churches the onus of preventing unauthorized attendance by Africans; but when the entire Christian church-except the Nationalists' Dutch Reformed Church-opposed the move, the bill was amended to exempt the churches from responsibility for attendance and placed it instead upon the nonwhites. ${ }^{123}$

118. E.g., 1 U.N. CoMm'N $\$ 784$; HaNdBoor 442; Moss, Apartheid in Action, 120 Just. P. 774 (1956).

119. 1 U.N. Comar'N $\$ 784$. Capetown is usually the most liberal.

120. Moss, supra note 118; Hepree, Censorship and Press Control in South Africa $25(1960) ; 1$ U.N. CoMm'N $\$ 784$. And as a consequence of racial problems the Union has barred television for black and white alike. N.Y. Times, Jan. 3, 1960, p. 22, col. 1.

121. See Landis 25, 49-50.

122. Id. at 50.

123. Reeves, The Anvil and the Hammers, Africa Today, Nov.-Dec. 1957, p. 17; Whyte, A Review of Legislation in 1957, RAcE REL. J., Jan.-June 1958, p. 21; Shepherd, Christian Liberty at Stake, Africa South, July-Sept. 1957, p. 5; Roman Catholic Bishops on the Blasphemy of Apartheid, Africa South, Jan.-March 1958, p. 13; H.A. DEB., April 1, 1957, col. 3950.

A letter from the late Anglican Archbishop of Capetown to the Prime Minister on the subject is quoted by Whyte, supra at p. 21:

We are commanded to render unto Caesar the things which be Caesar's and to God the things that are God's ....We believe that the matters dealt with in clause 29 (c) are among the matters that are God's.... We ... feel bound to state that if the Bill were to become law in its present form we should ourselves be unable to obey it or to counsel our clergy and peoples to do so.

One Nationalist replied :

It seems to me that certain church leaders mix up in their minds the idea of membership of a religious denomination and membership of a congregation, and also the freedom to attend a certain church. ***

I want to say very clearly and in all humility, but I would like to ask any theologist of any of the churches who support this attitude which is being adopted against the Bill, to prove to me that it is part of religious freedom that one should have the right to worship where one wishes to. That is not so....

H.A. Deb., April 1, 1957, cols. 3921-23. 
It is still possible that clergymen may be subject to severe punishment, including whipping, for counselling their parishioners not to obey the amended provisions. ${ }^{124}$ As a matter of practical application, the government has already banned from white areas the mosques of East Indians as well as certain Christian churches attended by African communicants (servants of white residents in the area).$^{125}$

In addition, the government has proscribed religious activities in certain native reserves. The Department of Coloured Affairs, with the assumed connivance of the Dutch Reformed Church, has banned all churches except the Dutch Reformed from Little Namqualand in the northwestern Cape ;26 $^{\mathbf{1 2 6}}$ ministers of an offshoot Calvinist Protestant Church have been convicted of leading religious services there as have lay members of the congregation for conducting prayer meetings. ${ }^{127}$

\section{Personal Relations}

Apartheid limits not only the church in which a person may be married but also the person he may marry. Since 1949 marriage between a white and a nonwhite has been prohibited by law although there has not been any similar restriction on intermarriage between members of the various nonwhite "races." 128 At the time the Prohibition of Mixed Marriages Act ${ }^{129}$ was passed, it was generally conceded that such "mixed" (white-nonwhite) mar-

124. Criminal Law Amendment Act, Act No. 81 of $1953, \S \S 1,2$.

125. N.Y. Times, July 1, 1956, p. 3, col. 6; 6 Arr. Drg. 238 (1959).

126. Gov't Notice No. 1634, Oct. 25, 1957. Reg. 88(i) provides that

Any person who, without the approval of the Commissioner or the magistrate of the area concerned,

(a) Holds, presides at or addresses, any meeting, gathering or assembly at which more than five person in the area ... are present at one time; or

(b) Permits any such meeting, gathering or assembly to be held in his house or on other premises or land under his control, shall be guilty of an offence.

Quoted in Carstens, The Dutch Reformed Church Militant, Africa South, Jan.-March, 1959, pp. $48,51,53$. Sub-regulation (ii) permits more than five persons to gather without a permit for certain events such as funerals, weddings, political meetings presided over by M.P.s and religious services presided over by the established church (Dutch Reformed) in the area. Id. at 51.

127. 5 AFr. Dig. 193 (1958) ; Cartens, supra note 126, at 52.

128. But the following statement was made in the Senate by a government representative recently :

[T] he evil is that this bastardization takes place on a large scale between the Natives and the Coloureds, and I want to tell you that the generation which arises from this has the brand of the criminal as it comes into the world. . .*** I feel so seriously about this matter that I would almost say that if it is necessary, legislation should be introduced so that the Immorality Act between these two races can also be applied....

SEN. DeB., April 22, 1960, cols. 2229-30.

129. Act No. 55 of 1949. Mixed marriages averaged less than 100 per year while there were some 25,000 marriages per year between whites. 
riages were very rare and that miscegenation was not socially acceptable. ${ }^{130}$ The purpose of the legislation appears to have been to prevent "passing" by colored persons rather than to bring about racial purity in the biological sense. ${ }^{131}$ The restrictiveness of the act, which makes it a penal offense for a marriage officer to perform a prohibited marriage as well as for a mixed couple to marry, ${ }^{132}$ has resulted in a number of civil actions to compel such officers to marry "doubtful" couples. ${ }^{133}$ It appears that the courts have generally labored to resolve favorably the difficulties of the couples before them, ${ }^{134}$ and at least one leading South African scholar has in private conversation confirmed this impression.

Not only marriage, but any sexual intercourse, between white and nonwhite is illegal under the Immorality Act." ${ }^{135}$ The purpose of this Act is "not to check immorality as such but . . . 'to try to preserve some sort of apartheid in what one may call prostitution ...." "136 Under the law there have been a number of prosecutions of mixed couples (European and colored) who had lived together for many years although not married; such families have been broken up and a three months' sentence imposed upon the partners. ${ }^{137}$ Appealed cases suggest that a favorite occupation of the police may become spying upon amorous couples lest they violate the law, ${ }^{138}$ while the result of arrests

130. CARTER 76; INT'L COMMN'N 57.

131. CARTER 77; INT'L COMM'N 57.

132. Act No. 55 of $1949, \S \S 2,4$.

133. E.g., Pedro v. Tansley, [1951] 4 So. Afr. L.R. 182 (C).

134. McWhinney, Race Relations and the Courts in the Union of South Africa, 32 CaN. B. REv. 44, 61 (1954).

135. Immorality Act, Act No. 23 of 1957, §§ 16(1), (2). Section 16(3) makes it a sufficient defense that the accused, if white, believed that the person with whom the offense was committed was white, or that the accused, if colored, believed that the person with whom the offense was committed was colored. The statute refers to "any immoral or indecent act." According to a South African commentator the purpose of such broad language is to permit conviction without proof of intercourse since it is often difficult to catch mixed couples in flagrante delicto or otherwise to obtain sufficient evidence to convict of unlawful intercourse. Lewin, Sex, Colour and the Law, Africa South, April-June 1960, pp. 63, 66.

136. CARTER 79.

137. Id. at 80; Lewin, supra note 135 , at 67 . But for an apparent change in attitude, see INT'L COMN'N 58.

138. See, e.g., the recital of facts in R. v. B. \& H., [1953] 2 So. Afr. L.R. 344 (C), and the comments of Mrs. N. B. Spilhaus, member of the Commission of Inquiry appointed by Prime Minister Hertzog in 1939, cited in Lewin, supra note 135, at 66; N.Y. Post, June 13, 1960, p. 32, col. 5 ; id., Feb. 24, 1961, p. 46, col. 2.

Some of the persons caught under the act include the (male) secretary to then Prime Minister Strijdom, a predikant (Dutch Reformed pastor), the headmaster of a school, a well known attorney, and numerous wealthy married farmers. N.Y. Times, Feb. 2, 1958, p. 22, col. 2; Lewin, supra note 135, at 67. In fact, so many Afrikaner men have been "caught out" that Lewin feels it likely that the government will try to hide the Afrikaners' "shame" by a new law prohibiting the press from publishing reports of these cases heard in court. Id. at 68 . 
in such cases is likely to be conviction of the nonwhite with acquittal of the white partner in a separate trial. ${ }^{130}$

\section{Liquor}

Under apartheid a nonwhite may not, even if his fortune permits, console himself with "the cup that clears today of past regrets and future fears." The sale of liquor to, or its possession by, nonwhites is prohibited except under permit. ${ }^{140}$ Stringent provisions empower the Minister to prohibit the sale of sprouted grain within five miles of an urban area, ${ }^{141}$ and in South West Africa nonwhites are forbidden to have dried lentils in their possession without permission lest they turn them into liquor instead of soup. ${ }^{142}$ Brewing and sale of the only alcoholic beverage allowed to nonwhites, "Kaffir beer," is generally a zealously guarded public monopoly due to the revenue which it produces for local governments; ; $^{143}$ this has led, as did the American "noble experiment," to homebrew and speakeasies. ${ }^{144}$ Somewhat more than $50 \%$ of all convictions of nonwhites are for violation of the Union's liquor laws. ${ }^{145}$

\section{Taxation}

Even in the field of taxation these is discrimination, largely between African and non-African. ${ }^{146}$ Nowhere is this discrimination more apparent than in the income tax, the only direct tax to which all inhabitants of the Union, re-

139. Manchester Guardian Weekly, Aug. 11, 1960, p. 4, col. 4; CARTER 81. Lewin states that since 1951 there have been an average of 300 prosecutions a year under the act. Lewin, supra note 135, at 67 . He also indicated that as prosecution has become more severe, the tendency has been noted for white women to take up prostitution, an occupation previously dominated by nonwhites. Id. at 68 .

140. Liquor Act, Act No. 30 of 1928, $\$ \$ 95,95(1), 101,122-30$; Urban Areas Act, Act No. 25 of $1945, \S 32$.

141. Urban Areas Act, Act No. 25 of 1945, § 35.

142. Conversation with South West African petitioners at the United Nations.

143. "Kaffir beer" is somewhat like the "near beer" of the early thirties in the United States. The Liquor Act defines kaffir beer in section 175 as: "The drink commonly brewed by natives from kaffir corn or millet or other grain and containing not more than two per cent by volume of alcohol"; HANDEOOK 258.

144. Police raids upon illegal stills operated by African women in Cato Minor, a native location referred to by visitors as one of the Union's worst slums, were claimed by the newspapers to have touched off the violent protests against apartheid which rocked Durban and large sections of Natal Province in the summer of 1959. N.Y. Times, June 19, 1959, p. 8, col. 1 ; June 30,1959, p. 3, col. 3. But an on-the-scenes commentator claims that application of the Group Areas Act was the primary cause and overall poverty a secondary one. Blumberg, Durban Explodes, Africa South, Oct.-Dec. 1959, p. 9. As to speakeasies-called shebeens-see, e.g., HandBook 260; InT'i Comar'n 62; N.Y. Times, Jan. 18, 1959, sec. 1, p. 9, col. 2 .

145. H.A. DEB., Feb. 3, 1959, col. 376 (Minister of Justice).

146. HANDBook 295 cites the Report of the Social and Economic Council (Rep. No. 7) : "Members of other racial groups who earned an income equal to the average Native income would generally be exempt altogether from direct taxation.' " 
gardless of color, are subject. Male whites pay under one schedule on their net income; a man with a wife and three children may earn as much as $£ 1,100$ without tax. ${ }^{147}$ Male Africans, on the other hand, are subject to tax on gross annual income over $£ 180$, without deductions or exemptions ; ${ }^{148}$ and they have to pay from 18 to 65 , eight years longer than Europeans. ${ }^{149}$ African women pay tax on their gross income over $£ 180$, even if they are married and their money is otherwise in the community; $;^{150}$ but the income of white married women is added to their husbands'-and there are lower rates for married men than for single. . $^{151}$

Even the African men who earn less than $£ 180$ are subject to a general ("poll") tax of $£ 1.15$ annually, ${ }^{152}$ as well as to a local ("hut") tax or quitrent, ${ }^{153}$ to taxes levied by the Bantu authorities, ${ }^{154}$ and often, if indirectly, to pass fees, ${ }^{155}$ none of which affect Europeans. The first two of these apparently were introduced as a means of obtaining cheap labor for the mines ${ }^{106}$ and have been continued ever since.

Tax receipts and exemption or extension certificates may be demanded of any African at any time by a vast number of authorized officials. ${ }^{157}$ Failure to pay taxes within three months of the due date is an offense punishable by

147. See Income Tax Act, Act No. 58 of $1960, \S 1$, schedule. Deductions or exemptions are permitted for dependents, business expenses, etc. Income Tax Act, Act No. 31 of 1941, $\S \S 10,11,13,58$ passim.

We know that they [the Africans] are now to pay an income tax on a different basis from that which we as Europeans, or white people pay. They are to pay an income $\operatorname{tax}$ on $£ 180$ a year, whereas Europeans or White people can go up to $£ 1,100$ a year, if it is a man and wife and three children, before they have to pay any income tax

SEN. DEB., April 1, 1960, col. 1678.

148. Natives Taxation and Development Act, Act No. 41 of 1925, §§ 2(1), as amended by Act No. 38 of $1958, \S 1 ; 2(1)$ bis (b), added by Act No. 38 of $1958, \S 1$.

The rates are: $5 \mathrm{~s}$ annually for income up to $£ 240 ; 15 \mathrm{~s}$ for each additional $£ 60$ or fraction thereof up to $£ 420$; and $£ 1$ for every $£ 60$ or fraction thereof above $£ 420$.

149. 6 Afr. Dig. 63 (1958).

150. Natives Taxation and Development Act, Act No. 41 of 1925, § 2(1) ter, added by Act No. 38 of $1958, \S 1$.

The rates are: $£ 1$ for each $\$ 60$ or fraction thereof above $\$ 180$.

151. Income Tax Act, Act No. 31 of 1941, $\$ \S 6(1)$ (d), 10(3) (ii), 13(2) (a), 58(1).

152. Technically, an African subject to the income tax pays that, and the amount paid is credited against the general tax due; but the poll tax must be paid even if the African's income is too low to be subject to the income tax. Natives Taxation and Development Act, Act No. 41 of 1925, \$2(1) quat, added by Act No. 38 of 1958, $\$ 1$.

153. Natives Taxation and Development Act, Act No. 41 of 1925, $\S 2(2)$, as amended by Act No. 28 of 1926, $\S 1$. For exemption of incompetents, aliens, students, and others, see $\S 4$.

154. See Landis 30.

155. HANDBOOK 294.

156. BRADY 414.

157. Natives Taxation and Development Act, Act No. 41 of 1925, § 7, as amended by Act No. 37 of 1931, § 3. And see text at note 167 infra. 
a fine of the amount due plus costs or in default thereof by imprisonment with or without hard labor. ${ }^{158}$ As one sympathetic observer stated, noting the hopeless position of a defaulter:

Once a tax-payer has failed to discharge his liability for any given year the accumulative debt becomes too great for him to meet ..... As year follows year his difficulty increases until at last the mere sight of a policeman's uniform is sufficient to send him into hiding . . . . 159

The allocation of funds raised by taxation of Africans further discriminates against this poorest segment of the country. While local taxes and quitrents go to local councils or Bantu authorities or to the Native Development Account and some general tax money goes to the Bantu Educational Account, part of the taxes go into the general revenues. ${ }^{160}$

Under the segregation policy, the African community is supposed to be a community completely apart, its separate existence financed from its own taxation .... As soon as improvement in an African's economic status makes it possible for him to contribute more than a basic amount to public revenue, he is at once brought under a law which draws his contribution away from the separate account for African development, that is, the Native Trust Account, and into the general revenue on which he and his people have no recognized claim. ${ }^{161}$

\section{ENForcement of Apartereid}

The preceding discussion of apartheid legislation has been largely limited to the substantive provisions of the law-what is permitted to or required of the various races. An equally important question is how the laws which provide such differential treatment for the various races are made effective.

Some answers to this question have been set out in connection with the specific statutes already discussed, such as the "idle" and "undesirable person" and other removal provisions of the Urban Areas Act. ${ }^{162}$ Certain others will be analyzed in the following section on the perpetuation of apartheid. ${ }^{163}$ This section deals primarily with statutory provisions not considered elsewhere.

\section{Passes}

Perhaps the most effective method of enforcing apartheid is also the most hated, the so-called "pass laws" or "pass system." In fact, the "system" is a combination of numerous independently conceived and often inconsistent

158. Natives Taxation and Development Act, Act No. 41 of 1925, § 9. In 1935 and 1936 there were 68,916 and 63,072 convictions respectively for failure to pay taxes; in 1936, 30,493 Africans served prison terms for failure to pay their taxes. HANDBOoK 301.

159. HANDBOOK 301.

160. May, The South African Constitution 474-75 [hereinafter cited as May].

161. HANDBOOK 300.

162. Landis at $43-46$.

163. See text beginning at note 219 infra. 
laws, many of which date back to pre-Union days. ${ }^{164}$ "System" refers far more to its consequences than to its organization. There is not even any one satisfactory definition of a pass, but in general Africans ${ }^{105}$ recognize as passes documents which: (1) are required of certain races only, (2) restrict freedom of movement and (3) may be required to be produced at any time, failure to produce being a criminal offense. ${ }^{168}$ At one time 27 or 28 passes were required of the average African male, including, inter alia, his current tax receipt, a copy of his service contract, permission to remain in an urban area. ${ }^{167}$ In this earlier period passes were required of African men only, and a substantial number of men were exempt for reasons of character, occupation (e.g., ministers, teachers), or for other similar reasons. ${ }^{108}$

The protagonists of passes argue that they prevent development of large pools of unemployed, vagrant Africans in urban areas, thereby preserving a "proper" labor supply in agriculture and mining, where labor is chronically short; and that they protect the established, urbanized African from unfair competition by newly arrived Africans, who supplement rural incomes by short-term city employment. ${ }^{169}$ Opponents have stressed the lack of freedom of contract and the cost to the national economy of artificially diverting labor

164. Handboor 275; 1 U.N. Conm'n $\$ \$ 487$, 489; Int'i Comar'n 27-2S. H.A. Deb., March 30, 1960, col. 4549 ("the pass laws are as old as civilization in our country. They date from the days of the Republics and were taken over at Union.")

165. There is some limitation on the right of travel and residence for Indians (see text at note 190 infra). Otherwise Africans are the only nonwhites generally subject to passes.

166. Handeoox 275; 1 U.N. Consm's § 490; Simons, Passes and Police, Africa South, Oct.-Dec. 1956, p. 52. In parliamentary debate an opposition member indicated that in her opinion the key factor in the pass system is the criminal penalty for failure to produce a pass on demand. H.A. DeB., March 30, 1960, col. 4522.

Thus many an African has run afoul of the law by leaving his pass behind while he stepped out on the stoep to bring in the dog or to comfort a crying child. The government has refused to accept amendments to the law which would permit an African who failed to produce his identity card on demand either (1) to produce it within seven days or (2) to be held guilty only if he failed to produce it without reasonable cause. See H.A. DeB., April 24, 1957, col. 4662. Cf. R. v. Khoza, [1958] 4 So. Afr. L.R. 401 (T) (failure to obtain reference book does not excuse failure to produce).

167. Simons, supra note 166, at 52 .

168. There were a few particular exceptions, but passes were not issued to women generally. Between 1940 and 1946, 23,500 Africans out of 360,179 in Johannesburg had received exemptions and in 1947 the total number of exemptions in the Union was 51,134. HANDBOOK 287.

169. HaNDBooK 289.

Each Bantu here in the Union who carries that pass book proves thereby that he is a Native of the Union of South Africa, that he belongs here, that this is his home, here within the Union of South Africa.

[T] hat pass book also serves as a sort of employment-providing document, showing that he is entitled to receive work in South Africa, that employers have the right to employ him....

[I]f you succeed in giving the Bantu employment opportunities through the medium of these pass books, you avoid unemployment and ... you prevent the Bantu 
from the areas where its productivity is highest. ${ }^{\mathbf{1 7 0}}$ In addition to moral and ethical grounds for opposition,, ${ }^{171}$ the pass laws represent probably the greatest source of day-in, day-out antagonism to the established order since the resultant "harrassing and constant interference with the freedom of movement of Natives .. . gives rise to a burning sense of grievance and injustice."172 It is impossible to determine accurately the number of Africans who are jailed each year for violation of pass laws, but estimates run up to $500,000 . .^{173}$

The worst aspects of the various pass laws presumably were corrected by the Abolition of Passes and Coordination of Documents Act ${ }^{174}$ in 1952. Under this statute every "native" over 16 is required to be fingerprinted and to obtain a "reference book." 175 The books are supposed to contain the

wages ... being forced lower as a result of unemployment. This pass book is, in other words, a means for the Bantu to safeguard his own standard of living and to improve it ....

SEN. DEB., April 5, 1960, cols. 1822-23.

170. H.A. DEB., June 18, 1957, cols. 8372, 8396-98, 8409-12; id., March 30, 1960, cols. $490-91$.

171. Former Senator Rubin had hinted that a reason for the insistence on issuing pass books to African women was the promotion of immorality between the police and the women. SEN. DEB., March 30, 1960, col. 1579.

172. HANDBook 81, 289-90, citing the Smit Committee report of 1942.

In fact the pass laws, apart from hounding Africans from birth to the grave, have created a dangerous spirit of hatred ... towards the police .... Pass laws make it possible for police to raid Africans at all hours of the day and night. The homes of our people, where men should enjoy some measure of privacy and peace, are raided weekly by the police for passes and liquor. . . Pass laws restrict the movements of innocent and law-abiding Africans by imposing curfew controls over them as if they were criminals. . . . Pass laws make criminals of otherwise decent and respectable Africans.

SEN. DeE., March 30, 1960, cols. 1593-94. And in the House it was said that "It is the pass book that enshrines the essential insecurity of these people in the urban areas." H.A. DEB., March 30, 1960, col. 4490.

173. Simons, supra note 166 , at 52 (over 300,000 ) ; H.A. DeB., June 18, 1957, col. 8372 $(450,000)$; United Party statement quoted in 6 AFr. Dig. 146 (1959) (500,000); H.A. DEB., March 30, 1960, col. 4489, quoting the Bureau of Census and Statistics for 1957 (more than 500,000). Africa Digest cites a report in the Star for Feb. 10, 1959, that $1,250,000$ Africans are prosecuted every year for trifling offenses (pass laws, movement control, labor regulations, and curfew restrictions) and more than 1,000,000 of those are found guilty. 6 AFr. Dig. 192 (1959).

In $1952 \mathrm{Dr}$. Verwoerd, then Minister of Native Affairs, admitted that his department spent $£ 340,000$ on the salaries of 350 clerks employed to issue the 500,000 forms required by the pass laws-and another $£ 10,000$ on printing costs. Simons, supra note 166, at 53.

174. Act No. 67 of 1952.

175. Act No. 67 of 1952, $\$ 2(1), 3(1)$ (a) ; 4(a), (b). Exempt Africans (chiefs and headmen, teachers, professors, lecturers, ministers of religion who are marriage officers, advocates, attorneys, medical practitioners, dentists, and holders of exemptions under the Native Administration Act) according to $\S 3(4)$ do not have to be fingerprinted, but they now receive "reference books"- thus substantially losing their exemption, although their passes do have covers of a different color ! 
African's identity card, ${ }^{176}$ information as to employment, ${ }^{177}$ and information as to the status of the African if he is a tenant laborer or squatter. ${ }^{178}$ By other legislation and regulations, however, the reference book must contain various additional special permits and certificates of exemption ${ }^{179}$ until an African representative is alleged to have stated in disgust that the title of the act would be correct if "Abolition of "were removed and it were called merely "Passes and Co-ordination of Documents."180

The number of arrests for violation of pass laws has already been indicated. However, one of the uses of such arrests must be detailed in the words of an observer:

By 1950 the system of private jails or "out-stations," ... was well established, with seven private jails dotted through the Transvaal .... These jails were built by the farmers' associations and then staffed, maintained and guarded by the Prisons Department, which hired out gangs of prisoners to farmers at two shillings per day per convict. Parallel with the system of private jails went the Prison Department's scheme of hiring out short-term prison offenders for work on the farm at $9 \mathrm{~d}$. a day. The official version was that men serving up to three months' imprisonment were offered work on farms and released under contract to the farmer ... for the remainder of their sentences. In 1949, 38,000 Africans were sent to work under this scheme.

$* * *$

In the townships it was common knowledge that the Labour Bureaux of the Native Commissioners' Courts and the local Pass Offices were dragnets for farm labour, and in Alexandra Township every year, as the reaping season approached, the police raids for pass offenders became noticeably more frequent. ${ }^{181}$

176. Issued under the Population Registration Act.

177. To be entered by employers. In a test case, R. v. Madondo, [1956] 2 So. Afr. L.R. 682, the Natal Provincial Division held that a copy of the service contract rubber-stamped as to date and the name of employer met the requirement that the document be endorsed by the employer.

178. Act No. 67 of $1952, \S 8$. The act also provides that no alien African shall enter any district without a permit from the native commissioner except in the course of employment and that no African under 16 may contract to work away from home without an official document of identification indicating that his father or guardian has consented. Act No. 67 of $1952, \S \S 9,10(1)$.

179. See, e.g., Proc. No. 41 (1959), So. Afr. Gazette (March 6, 1959), p. 6, requiring special permits for Africans outside locations during curfew hours in urban local authority Clanwilliam Area.

180. 1 U.N. CoMrM'N § 508, citing 32 J. PARL. CoMrM. 545 (1952).

181. First, Bethel Case-Book, Africa South, April-June 1958, p. 14. Almost 15 years earlier Hellmann wrote that:

Prisoners may be put to work for private employers or public organizations under contracts entered into by the Director of Prisons. ... [A]pproximately 1,400 longsentence Non-Europeans are supplied daily to certain gold mines; Non-Europeans are hired out to farmers and other private employers, and extensive use is made of free prison labour by government departments and institutions ....

HANDBOOK 106. 
It is well known that an African arrested for a pass violation may escape trial and the almost certain conviction to follow (with its consequent effect on his right to be in an urban area) by immediately "volunteering" for a period of farm labor. ${ }^{182}$

The 1952 act introduced another, more revolutionary aspect of enforcement by requiring reference books of all Africans instead of males only. ${ }^{183}$ When the Minister of Native Affairs announced that African women would soon have to carry passes, ${ }^{184}$ the reaction, though virtually unreported in the Ameri-

182. The Minister of Justice has announced that:

As far as our farmers are concerned, I want to say that our farmers have never been against taking offenders into their service. They [sic] come and fetch them and give them employment and they help us to rehabilitate them ....

H.A. DEB., Feb. 3, 1959, col. 383.

Green states unequivocally that "in reality the purpose of these [pass] laws is the provision of cheap farm labour." He goes on to cite another authority that "'once convicted of being passless, (the Natives) have the choice to serve their sentence or voluntarily to accept service on the farms. If they choose the latter, the prosecution is withdrawn.' "Green, Human Rights and the Colour Problem, 3 CuRr. LegaL PRoB. 236, 259 (1950).

But the service, Green adds, is not always voluntary : In 1949 a new jail was opened at Leslie in the eastern Transvaal which had been built by the Leslie Farmers' Association Labour Supply Company; the company had 50 shareholders, each holding shares worth $£ 40$. The jail held 300 prisoners, who were hired out to the shareholders at one shilling and ninepence per day. "These prisoners are transported from jail to farm padlocked in wire cages, and even local inhabitants have not hesitated to use the word 'slavery. " Id. at 259.

The International Commission of Jurists in its report on the rule of law in South Africa presents in Appendices $D$ and $E$ the petition and supporting affidavits in two cases of Africans taken involuntarily to white farms. It is believed the circumstances and conditions portrayed in these two appendices are repeated throughout the country. The following excerpts are taken from the administrative circular quoted in Appendix C, now applicable to foreign "natives" only :

1. It is common knowledge that a large number of natives are daily being arrested and prosecuted for contraventions of a purely technical nature ***

3. The Department of Justice, the South African Police and this [Native Affairs] Department ... have evolved a scheme, the object of which is to induce unemployed natives now roaming about the streets . . . to accept employment outside ... urban areas. ***

6. The scheme has now been in operation in the large centres for some time, and ... the procedure described below is followed in dealing with natives arrested....

(a) Natives arrested between 2 p.m. on Sundays and 2 p.m. on Fridays are not charged immediately after arrest, but merely detained by Police.

(b) Natives so detained are removed under escort to the district labour bureau and handed over to the employment officer, at such times as suits local conditions ....***

(f) The natives must be offered such employment as is available in nonprescribed (rural) areas. Priority should be given to farm labour in this connection.

(g) Natives who on account of their declining to accept employment are not released, are returned to the South African Police for prosecution ....

183. Act No. 67 of 1952, §§ 2(1), 3(1), 13.

184. Joseph, Women and Passes, Africa South, Jan.-March 1958, p. 26. 
can press, was of a totally unexpected violence. All over the Union women joined in spontaneous pass-burning demonstrations. ${ }^{185}$ The government responded by using every means available to enforce its own pass laws, which were themselves supposed to be enforcement measures. It withdrew old age pensions from rebellious women and even from men whose wives or daughters refused passes; it refused tax payments from men whose womenfoll had refused passes, leaving them open to criminal penalties for arrears; its officers refused to perform marriages for women without passes; and it even authorized district surgeons to refuse care to passless Africans. ${ }^{136}$ In Zeerust, near Bechuanaland, where anti-pass activity, reinforced by local grievances, resulted in riots, the local post office was closed "to protect government property," the bus to the outside world was discontinued, and the names of children who left school to protest the principal's support for passes were put on a blacklist to prevent their ever obtaining any schooling. ${ }^{187}$ In addition to these extraordinary measures, ${ }^{188}$ the government employed customary criminal remedies. Women were fined or jailed for destroying their pass books ("government property") and for refusing to register for passes. ${ }^{180}$

Indians, too, require passes when they wish to travel or reside outside the province in which they were born. ${ }^{190}$ The earliest restrictions on Indian immigration were imposed by the Boer republics in the nineteenth century, and in the second half of the twentieth century third and fourth generation Indians are still "treated within their own land as immigrants."191

\section{Restriction of Injunctive Relief Against the Government}

The government does not stop with a positive pass system to enforce apartheid; it has also enacted negative or preventive measures which inhibit non-European attacks on or defenses against executive action in applying apartheid. Some of these have been discussed previously in relation to the Group Areas and Western Areas Removal Acts, ${ }^{192}$ and certain others will be discussed in the following section. ${ }^{193}$

185. Ibid.; Joseph, Women and Passes (II), Africa South, April-June 1959, p. 20; H.A. DeB., June 18, 1957, col. 8370.

186. Joseph, sıpra note 184, at 29; Fairbairn, Zeerust: A Profile of Resistance, Africa South, April-June 1958, p. 33.

187. Fairbairn, supra note 186, at 33.

188. Thousands of Africans have fled from the area, and no amount of diplomatic language can disguise the fact that those who have crossed the border into Bechuanaland are political refugees who have found asylum in a neighboring state.

Dey, Peaceful Evolution or Bitter Conflict, The Forum, April, 1958, p. 9.

189. R. v. Motlagomang, [1958] 1 So. Afr. L.R. 626 (T); R. v. Mojafe, [1958] 2 So. Afr. L.R. 116 (T). Joseph, supra note 185, at 20. Despite intense opposition the government has proceeded implacably to make the law effective. See 6 Arr. DIG. 146 (1959).

190. BROOKES \& MACAULAY $52 ;$ HANDBO0K 206-07.

191. Brookes \& MacaULAY 52 .

192. See Landis 23-28.

193. See text beginning at note 219 infra. 
One of the most flagrantly undisguised racial acts of this sort is the Natives (Prohibition of Interdicts) Act of $1956 .{ }^{194}$ Under this statute an African is prohibited from obtaining an interdict (similar in effect to an injunction) to suspend the execution of an order (1) to vacate, depart, or withdraw from, to be ejected or removed from, not to return to, or not to be in or to enter any place or area; (2) to be removed from any place or area to any other place or area ; or (3) to be arrested or detained for the purpose of his removal or ejectment from any place or area. The act further provides that no appeal against or review of proceedings in respect of any such order or any conviction or finding upon which such order is based shall stay or suspend the execution of the order or removal in consequence thereof. ${ }^{195}$ As a final insult, the statute was made applicable to stays or suspensions in effect on its effective date. ${ }^{108}$ If any removal order or a conviction or finding on which such an order is based is found to be invalid, the African is limited by the act to compensation in the form of damages and must, apparently, forego restoration to his former place or condition even if that would be possible. ${ }^{107}$

According to the Minister of Native Affairs, the act was designed to prevent the abuse of legal procedure "as a demonstration."198 But the opposition, citing a long list of earlier landmark cases which would have been affected by this legislation, ${ }^{109}$ claimed that the act was insolent and vindictive:

insolent because it will enable the Minister to treat the courts of law with contempt and to lay down what cases and orders that court may try, in dealing with cases in which a Native is the plaintiff ... [and] vindictive because its purpose is to deprive the Natives of a safeguard which they have shared with every citizen of South Africa ever since our courts were established $\ldots .^{200}$

Another M. P. added,

It is no good saying that this Bill preserves the powers of the Court which can compensate the victim for illegal removal. What is the value of the

194. Act No. 64 of 1956.

195. Act No. 64 of $1956, \S 2$.

196. Act No. 64 of $1956, \S 3$. The act applies to such orders or classes of orders as the Governor-General shall specify in the Gazette. Id., § 5 .

The opposition stated in parliamentary debate that even before the 1957 amendment to the Urban Areas Act was enacted, the Minister had issued a proclamation extending the provisions of the Prohibition of Interdicts Act to revised $\S 30$ of the Urban Areas Act, Act No. 25 of 1945 (removal of Africans). H.A. DeB., April 4, 1957, col. 4083.

197. Act No. 64 of $1956, \S 4$.

198. H.A. DEB., May 23, 1956, cols. 5943-48.

199. Id., col. 5953. The list included: R. v. Hodos, [1927] So. Afr. L.R. 10 (T) (conviction for failure to live in native residential area under Urban Areas Act of 1923); Benoni Town Council v. Mallela, [1939] So. Afr. L.R. 671 (T) (eviction from stand in native location under invalid regulation); Para v. Vereeniging, [1951] 1 So. Afr. L.R. 610 (T) (removal order under Urban Areas Act); Mosii v. Motseoakhumo, [1954] 3 So. Afr. L.R. 919 (AD) (removal under Native Administration Act of 1927).

200. H.A. Deb., May 23, 1956, col. 5950. 
compensation if that victim has lost his home, lost his job and lost everything! !201

To complement this statute there is a general provision requiring 72 hours' notice to the government when an application is made for a rule nisi operating as an interim interdict against the government, unless the court permits such shorter notice as it deems reasonable. ${ }^{202}$ Informed South African sources state that the courts require the full notice period when an African seeks a rule nisi but will customarily make the temporary interdict effective immediately when sought by a white petitioner. ${ }^{203}$

\section{Administration of Justice}

Throughout Union history the opposition (whatever its party designation) has complained of the absolute discretion vested in the executive and the lack of effective judicial review of administrative action. ${ }^{204}$ Yet the courts have always had a proud reputation for even-handed administration of justice. ${ }^{205}$ Today, however, it is commonly said that the Nationalist government has passed over the senior and best counsel and reached deep into the ranks of advocates to place sympathetic Nationalists on the bench, and that the judiciary is less of a bastion of justice than formerly. ${ }^{206}$

In addition to this rather intangible aspect of discrimination in the administration of justice, there is a whole congeries of attitudes and practices which are hard to document but which are nevertheless fundamental to the administration of justice. In the field of police administration, for example, it has been claimed that the bulk of police recruits come from rural Afrikaans-speaking communities where prejudice against non-Europeans is strongest, that there is an attitude of "mutual distrust, suspicion and dislike" between the police and the nonwhites in the Union, and that brutal methods towards nonwhites are at least unofficially sanctioned. ${ }^{207}$

Even in the courts the handicaps of nonwhites do not cease. These handicaps arise in the first place out of their poverty, which inhibits the employment of adequate counsel and encourages accession to unjust verdicts to limit the precious time of hourly or daily paid employees whose employment may hinge

201. Id., col. 5971.

202. General Laws Amendment Act, Act No. 62 of 1955, § 35.

203. Conversation with South African advocates.

204. MAY, ch. XIV passim.

205. Brookes \& Macaulay 45; Handbook 46; see, e.g., Radebe v. Hough, [1949] 1 So. Afr. L.R. 380 (AD) (social status of party is irrelevant); Tayob v. Ermelo Local Road Transp. Bd., [1951] 4 So. Afr. L.R. 440 (AD).

206. Rubin, Nationalist Contempt of Coutr, Africa South, Jan.-March 1960, pp. 5, 9-11; conversation with members of the South African Bar.

207. HANDBOoK 75-77; the police are, in addition, overwhelmingly young and without mature judgment. N.Y. Times, May 8, 1959, p. 2, col. 3. Cf. N.Y. Times, April 5, 1960, p. 1, col. 2 (police use clubs, bullwhips to force protesters back to work). 
on regular attendance and no outside "trouble."208 In practice bail is seldom granted by a magistrate unless the police consent, and they usually oppose it in the case of non-European defendants. ${ }^{209}$ At the trial itself a nonwhite defendant often is not entitled to a jury trial although a white accused of the same crime would be. ${ }^{210}$ And if he is entitled to a jury trial, it is likely to be of little value to him, for jurors all are white and hence cannot represent the defendant's peers in a society which argues that each "race" has inherently different characteristics. ${ }^{211}$ Indeed, most nonwhites prefer trial before a judge and assessors, particularly if their defense involves a denial of evidence given by a white witness. ${ }^{212}$ As a matter of law a court may in certain cases find that the same act done with the same motivation by a nonwhite is a crime although it would not be one if committed by a white. ${ }^{213}$

In terms of convictions and acquittals in criminal actions expert observers believe that nonwhites are consistently convicted in a greater proportion of cases than whites although the police are more thorough in investigating and more cautious in bringing charges when the defendant is white. ${ }^{214}$ An analysis of convictions of murder and lesser included offenses as related to the race of the accused and the victim, shows a striking difference which apparently reflects strong racial bias :

When it is a Non-European who has been killed, the discrimination operates to the advantage of the accused, whether Non-European or European

208. Hayman, Legal Aid for the Poor in South Africa, 26 J. CoMr. LEg. \& INT'L I. (3d ser.) Pt. III, at 12 (1944).

209. HANDBOOK 72 .

210. In all cases in which a chief or headman has jurisdiction and in all cases of a "mixed" crime-i.e., when both the accused and the complainant are not of the same race. Landis 35-36; MAX 258.

211. Criminal Procedure Law, Act No. 56 of 1955, § 114; HANDBook 66.

212. HANDBOOK 76, 77.

213. R. v. Olakawu, [1958] 2 So. Afr. L.R. 357 (C). In this case the court affirmed the conviction of an African of the common law crime of crimen injuria committed by handling a "mash note" to a white gir1:

Although the test as to what constitutes an impairment of dignity must naturally be an objective one, regard can, I think, rightly, be had to the complainant's reaction to the accused's conduct. She says she felt insulted .... That she ascribes her feeling of being insulted to the fact that the accused was a Native, only serves to emphasize a fact to which our Courts have frequently had regard, namely, that the difference in colour between the complainant and the accused is an "aggravating" feature. . . . By "aggravating" feature I understand these decisions to mean, not that what would not otherwise be an injuria becomes such merely because of the difference in colour between complainant and the accused, but rather that what might otherwise be regarded as a trifling injuria not meriting punishment, may, depending upon the circumstances of the particular case, become a crimen injuria. The difference in colour, therefore, between the parties in this case is clearly a factor in the decision of whether a crimen injuria has been proved.

Id. at 360-61 ( $\operatorname{van}$ Winsen, J.).

214. HANDBOOK 74. 
... Not only is less value attached to the life of a Non-European, but Non-Europeans as a group are assumed to observe low standards of morality and self-restraint. When the offence is committed on a European, however, the same assumption, together with the desire to emphasize the sanctity of a European life, is made the reason for . . . securing a conviction if at all possible ....215

The sentencing of criminals also appears to depend upon their race. Thus "the treatment of the European offender is mainly reformative, while, in punishing the Non-European, the emphasis is placed upon the deterrent and retributive aspects of the penal system." 210 Thus, corporal punishment is limited almost entirely to nonwhite offenders; whites are never hanged for the murder of a nonwhite, but nonwhites are usually hanged for the murder of a white; and only nonwhites are hanged for rape, and then only for the rape of a white woman.217 Furthermore, statistics suggest that the Executive is influenced by racial considerations in granting reprieves in murder cases. ${ }^{218}$

\section{Perpetuation of Apartheid}

In one sense all enforcement measures perpetuate apartheid, for by ensuring that its various provisions are put into effect routinely day after day they provide the momentum which keeps the system operating. The present section limits discussion to those measures which are designed primarily to isolate the disenchanted, to negative their influence, and to prevent their effective opposition.

\section{Restriction of Franchise}

The first of these measures is the removal of the franchise from all nonwhites, who of course have the most immediate and urgent interest in ending apartheid.

Historically speaking, the voting rights of nonwhites have always been extremely limited. Law and custom limited the vote to whites in the Transvaal and the Orange Free State, and only whites might be elected to office in those colonies. ${ }^{219}$ In Natal qualified nonwhites were entitled to vote although in fact only the colored ever enjoyed suffrage. ${ }^{220}$ The Cape made no distinction, at least in theory, on the basis of color or race; in Cape Town nonwhites have sat on municipal bodies since the early years of the Union, and coloreds still

215. Id. at 99.

216. Id. at 97.

217. Id. at $97-98$.

218. Id. at 99.

219. Id. at 27; 1 U.N. Conar'N \& 466; McWhinney, Race Relations and the Courts in the Union of South Africa, 32 CAN. B. Rev. 44, 50 (1954).

220. HANDBooK 27, 37; 1 U.N. Conm's \& 466. In 1935 the registered voters in Natal Province included: Whites 91,762; Africans 1; Asians 10; coloreds 343. Msy 93. 
do. ${ }^{221}$ In 1936, when the first act restricting the franchise was enacted, ${ }^{222}$ the registered voters of the Cape included 382,103 whites, 21,596 coloreds, 1,401 Asians, and 10,628 Africans. ${ }^{223}$

Because of the two substantially different traditions of treating nonwhites, the Union "constitution" (the South Africa Act of 1909), provided for the perpetuation of the suffrage of nonwhites to the extent that they were entitled to vote at the time the Union was formed.224 This provision was "entrenched" by providing that it might be amended only by a two-thirds vote of Parliament sitting as a single body. ${ }^{225}$

In 1936, Parliament, following the prescribed procedure, removed all Africans from the common voters' roll in the Cape and put them on a special voters' roll, entitling them to elect three white ${ }^{226}$ members to the Assembly and two white members to the Cape Provincial Council ;22 the statute also provided that the Africans ${ }^{223}$ of the entire Union might elect four white senators to represent them. ${ }^{229}$ As a sop, the statute created a Natives Representative Council, with advisory functions only. ${ }^{230}$ The Council, however, was abolished by the Bantu Authorities Act after the Africans had expressed their opposition to apartheid by refusing to take part in its activities. ${ }^{231}$

221. HandBook 27, 34; Brookes \& Macaulay 151.

222. Representation of Natives Act, Act No. 12 of 1936.

While the franchise of non-whites was not reduced prior to 1936, it should be noted that it was decreased in relative effectiveness by Act No. 18 of 1930, which enfranchised all adult white women, and by Act No. 41 of 1931, which granted universal suffrage to all white male Union Nationals over 21. McWhinney, supra note 219, at 50.

223. MaY 93.

224. 9 Edw. VII, ch. 9, § 35(2).

225. South Africa Act of 1909, 9 Edw. VII, ch. $9, \S 152$.

226. Representation of Natives Act, Act No. 12 of 1936, $\$ 15(1)$. The qualifications for the representative are the same as for all other members of the House: "a British subject of European descent." South Africa Act of 1909, 9 Edw. VII, ch. 9, § 44(c).

227. Act No. 12 of $1936, \S \S 6(1)$ (a), (b) ; 7(1), (2); 19(1).

228. Election is actually by "electoral colleges" consisting of voting units such as local councils, native advisory boards, electoral committees, and chiefs or headmen of tribes not organized into any of these units. Act No. 12 of $1936, \S \S 3,4$. Each voting unit had the strength of the number of taxpayers it represented, and a unit rule was in effect as to each represented group. MAY 101-04.

In response to a question in Parliament, the Minister of the Interior stated that in 1959 the number of Africans registered to vote in electoral circles in the Cape was: Cape Western-9,691; Cape Eastern-3,655; Transkei-4,190. H.A. DeB., April 20, 1959, col. 4304.

229. Act No. 12 of 1936, $\S \S 2(1), 11(1)$. The qualifications are the same as for other Senators: "a British subject of European descent." South Africa Act of 1909, 9 Edw. VII, ch. $9, \S 26$ (d).

Section 2(2) provided that if the Governor-General felt that civilization and local government had advanced sufficiently among the Africans, he might allow them increased representation, not to exceed six in all.

230. Act No. 12 of $1936, \S \S 20,27,28$.

231. Act No. 68 of 1951, § 18. See MAY 500. 
Ten years after the African franchise was limited, the government offered limited representation in the federal Senate and Assembly as well as in the Natal Provincial Council to the Indians of the Union as a quid pro quo for further restrictions on their land rights. ${ }^{232}$ The Indians refused to recognize the political rights gained at such a price; and before they could become effective, the provisions granting the limited franchise were repealed. ${ }^{233}$

Although elimination of the Africans' white representatives from Parliament probably was not foreseeable in 1936, it had not been unexpected since the Bantu Authorities Act in 1951. However, many political sophisticates who saw the direction of events for Africans appear to have been totally unprepared for the Nationalist maneuvers to remove the Cape colored voters from the common roll. ${ }^{234}$ The "constitutional crisis," which began with the passage by the two Houses of Parliament sitting separately of the Separate Representation of Voters Act ${ }^{235}$ in 1951 and ended only with the passage, in prescribed manner, of the South Africa Act Amendment Act ${ }^{236}$ in 1956, brought home conclusively to the country's colored population that they no longer were a privileged class of nonwhites. ${ }^{237}$ This aspect of apartheid has been so extensively commented upon ${ }^{238}$ that only the briefest summary of events will be undertaken here.

232. Asiatic Land Tenure and Indian Representation Act, Act No. 28 of 1946. The representatives were to be elected on a communal basis, and it was possible, by a strange anomaly, that the representatives to the Natal Provincial Council might have been Indians. Brookes \& Macaulay 146; Hellmann, Ractal Laws versus Econoaitc and Soctal FoRCES 6 (1955).

233. Act No. 47 of $1948, \$ \S 2-5$.

234. When the Report of the 1929 Committee of the Imperial Conference came up for discussion in the house of assembly of the Union on April 22, 1931, it was stated from the government benches that parliament had a moral obligation to respect the "entrenched" clauses of the South Africa Act, and a resolution was passed by the house acknowledging that these clauses would be respected both in the spirit and in the letter of the South Africa Act, as passed in 1909 ... .

Kennedy \& Schlosberg, The Law and Custom of the South African Constitution 102-03 (1935) [hereinafter cited KeNNEDy \& SchlosBerg], citing H.A. DeB., April 22, 1931, col. 2739, and Keith, Speeches and Documents on the Brirish Donirnions 288, 290, 291.

It has been pointed out that out of $1,300,000$ colored inhabitants of the Union (at the time of these statistics) only 50,000 voted; and the ratio of colored representation to white was $4: 150$. Nevertheless, the concentration of colored voters in certain sections of the Cape enabled them to take part in the election of 55 members of the Assembly, and in 25 constituencies their say in the final vote was substantial. McWhinney, Race Relations and the Courts in the Union of South Africa, 32 CAN. B. Rev. 44, 54, nn.29 \& 30 (1954) (referring to 32 J. PARL. CoMM. 601 (1951)).

235. Act No. 46 of 1951.

236. Act No. 9 of 1956.

237. BRADY 418-19.

238. See, e.g., May 50-65; Cowen, Legislature and Judiciary: Reflections ont the Constitutional Issues in South Africa: Part I, 15 Modern L. REv. 282 (1952) ; Cowen, Legislature and Judiciary: Reflections on the Constitutional Issues in South Africa: Part II, 16 Modern L. Rev. 273 (1953); Cowen, The Entrenched Sections of the South Africa Act, 70 
The 1951 statute removed Cape coloreds ${ }^{239}$ to a separate roll and entitled them to vote, by electoral districts, for four white representatives in the House and two white representatives in the Provincial Council.240 The GovernorGeneral was to nominate an additional senator to represent the coloreds in Parliament. ${ }^{241}$ An Advisory Board for Coloured Affairs was created ${ }^{242}$ with three coloreds nominated by the Governor-General from Natal, the Orange Free State, and the Transvaal, and eight members from the Cape. ${ }^{243} \mathrm{~A}$ colored voter challenged the validity of the statute because of the manner of passage; on appeal from a decision for the government, the Appellate Division, to the amazement of all but a prescient few, reversed ${ }^{244}$ and held that the relevant portions of the South Africa Act did bind the South African Parliament despite the subsequent devolution of power from the British Parliament through the Statute of Westminster. ${ }^{245}$

Since the Nationalist government did not have a two-thirds majority of the entire Parliament, it enacted a statute the next year to make judgments of the Appellate Division which declared acts of Parliament unconstitutional subject to review by the "High Court of Parliament," i.e., by Parliament itself sitting as a special review court. ${ }^{246}$ The colored appellant in the "first vote case" challenged this statute also, and the Appellate Division again decided in his favor. ${ }^{247}$

S.A.L.J. 238 (1953) ; Gray, The Sovereignty of Parliament Today, 10 U. Toronto L.J. 54 (1953); McWhinney, The Union Parliament, the Supreme Court, and the 'Entrenched Clauses' of the South Africa Act, 30 CAN. B. Rev. 692 (1952) ; McWhinney, Race Relations and the Courts int the Union of South Africa, 32 CaN. B. Rev. 44 (1954); Northey, The Separate Representation of Voters Case, 28 N.Z.L.J. 234 (1952); Themaat, Legislative Supremacy in the Union of South Africa, 3 U.W. Austz. ANN. L. Rev. 59 (1954); Wade, The Senate Act Case and the Entrenched Sections of the South Africa Act, 74, S.A.L.J. 160 (1957); Griswold, The 'Coloutred Vote Case' in Sonth Africa, 65 HARv. L. Rev. 1361 (1952); Griswold, The Denise of the High Court of Parlianent in South Africa, 66 HARv. L. Rev. 864 (1953) ; Constitutional Crisis and Basic Norm in South Africa, 1 Sydney L. Rev. 64 (1953) ; Comment, 30 Can. B. Rev. 734 (1952); Comment, 35 Can. B. Rev. 1203 (1957); Kolts, Minister of Interior versus Harris and the South African High Court Act, 1 SyDNEY L. REv. 113 (1953).

239. "Non-Europeans" other than Africans were permitted to continue on the common roll in Natal Province, but, once removed, a name might not be reinstated, and no new names might be added to the roll. Act No. 46 of 1951, \$\$ 11 (ii), 13.

240. Act No. 46 of $1951, \S \S 2,4,6,9,11$.

241. Act No. 46 of $1951, \S 7$.

242. Act No. 46 of 1951, § 18. Subsequently renamed the "Union Council for Coloured Affairs," by the Separate Representation of Voters Amendment Act, Act No. 30 of 1956, $\S 2$. 243. Act No. 46 of $1951, \S 14$.

244. Harris v. Minister of Interior, [1952] 2 So. Afr. L.R. 428 (AD). See MAY 50-51 n.78.

245. 22 Geo. 5 , ch. 4 (1931). For representative opinions on the effect of the statute see, e.g., Kennedy \& Schlosberg 100; Pollak, The Legislative Competence of the Union Parlianent, 48 S.A.L.J. 269 (1931).

246. The High Court of Parliament Act, Act No. 35 of 1952, §§ 2, 3 .

247. Minister of the Interior v. Harris, [1952] 4 So. Afr. L.R. 769 (AD).

May suggests that the government blundered by appealing to the Appellate Division in 
Twice thwarted by the courts, the Nationalists finally solved their problem by reapportioning the Senate, adding new seats gerrymandered to give them control of two-thirds of all parliamentary seats. ${ }^{248}$ Having achieved this intermediate strategic position, they then put the South Africa Act Amendment Act into effect by passage in the constitutionally prescribed manner, at the same time limiting the power of the court to review legislation to questions affecting the entrenched clauses. ${ }^{249} \mathrm{~A}$ statute was enacted at the same session to require all members of provincial councils to be white. ${ }^{250}$ For a third time government's action was challenged in the courts, but although the Senate and South Africa Act Amendment Acts, read together, represented another means of circumventing the limitations of the entrenched clauses, the Appellate Division, with a single dissent, found that the method taken was not unconstitutional, however deplorable it might be. ${ }^{251}$

Since Africans are no longer represented at all in the legislature, their only protests must be extra-parliamentary. However, the government has enacted stern measures to prevent just such protests, whether peaceful or violent, and whether made by the Africans themselves or by their meagre handful of white sympathizers.

\section{Limitations on Free Association}

Although the Suppression of Communism Act ${ }^{252}$ has received the most publicity, it is only one of a whole congeries of statutes by which peaceable op-

the "second Harris case." MaY 61-65. "Once it had attempted defiance of the courts by enacting the High Court of Parliament Act, it should not have contested the validity of the measure in the courts, because by doing so it acknowledged the testing right." Id. at 61 .

248. Senate Act, Act No. 53 of 1955. The Senate Act was passed for two reasons: (1) to ratify the Separate Representation of Voters Act and (2) to place the sovereignty of Parliament beyond any doubt. SEN. Deb., May 9, 1960, cols. 2821-22 (government spokesman). For an explanation of how this act (providing for elections on a winner-takes-all basis in each province) gives an almost clean sweep to the Nationalists, see MAY 73-78. For a definitive analysis of the construction of voting constituencies, see CARTER 150.

The Senate Act, Act No. 53 of 1959, somewhat changes the method of choosing Senators; it does not, however, in any way jeopardize the control of the Nationalists. H.A. DEB., Feb. 22, 1960, col. 1956.

249. Act No. 9 of 1956, § 2. The government also enacted the Appellate Division Quorum Act, Act No. 27 of 1955, as amended, Appellate Division Quorum Act, Act No. 1 of 1959, providing that the quorum of the Appellate Division necessary to determine the validity of an act of Parliament shall be 11, instead of the three or five required in other cases.

250. Separate Representation of Voters Amendment Act, Act No. 30 of 1956, § 1. To reinforce its majority among white voters, the Nationalists in 1958 enacted the Electoral Law Amendment Act, Act No. 30 of 1958, § 1 of which amended the Electoral Consolidation Act, Act No. 46 of 1946, $\$ 3$, by lowering the minimum voting age to 18 . It is generally believed that younger voters will support apartheid in greater numbers than older members of the community. Scrutator, The Burger, The Transvaaler, and the Teenager, The Forum, Sept. 1958, p. 8.

251. Collins v. Minister of the Interior, [1957] 1 So. Afr. L.R. 552 (AD).

252. Act No. 44 of 1950, as amended. 
position to government policy is suppressed. These statutes limit freedom of association; suppress criticism of government policy; prohibit peaceable public assembly; repress opposition political groups; and restrict freedom of movement.

The Suppression of Communism Act itself provides the government with a simple means of restricting association and limiting the rights of individuals in the guise of preventing subversion. ${ }^{253}$ The act commences with long, complex, and all-embracing definitions of "communism" and "communist."254 It then declares the communist party of South Africa ${ }^{255}$ an unlawful organization 256

253. The source of this statute was said in Parliament to be the 1920 British statute which also declared a state of emergency and provided for the issuance of regulations by the executive in case of action or threatened action interfering with community essentials (water, fuel, etc.). H.A. DEB., March 29, 1960, col. 4345.

254. "Communism" means

the doctrine of Marxian socialism as expounded by Lenin or Trotsky, ... the Comintern ... [or] the Cominform ... or any related form of that doctrine . . . in particular, any doctrine or scheme-

(a) which aims at the establishment of a despotic system of government based on the dictatorship of the proletariat under which one political organization only is recognized ... or

(b) which aims at bringing about any political, industrial, social or economic changes within the Union by the promotion of disturbance or disorder, by unlawful acts or omissions [or by threats of same] ... or

(c) which aims at bringing about any ... [such] change within the Union in accordance with the directions or under the guidance of or in co-operation with any foreign government ... one of whose purposes ... is to promote the establishment within the Union of any political, industrial, social or economic system . . . similar to any system ... in any country which has adopted a system of government such as is described in paragraph $(a)$; or

(d) which aims at the encouragement of feelings of hostility between the European and non-European races of the Union the consequences of which are calculated to further the achievement of any object referred to in paragraph $(a)$ or (b) ....

Act No. 44 of 1950, $\$ 1$ (ii).

"Communist" includes any person

who professes or has at any time ... professed to be a communist or who, after . . . making such representations as he may consider necessary, is deemed by the GovernorGeneral ... to be a communist on the ground that he is advocating, advising, defending or encouraging or has at any time ... within or outside the Union, advocated, [etc.] ... the achievement of any of the objects of communism ... or ... has at any time ... been a member or active supporter of any organization outside the Union which professed, by its name or otherwise, to be an organization for propagating the principles or promoting the spread of communism....

Act No. 44 of 1950, 11 (iii), as amended by Suppression of Communism Amendment Act, Act No. 50 of 1951, § 1(a) (emphasis added). See INT'L CoMM'N 51 ("So if you were a Communist forty years ago, you are a Communist today. And, whether you are a Communist or not, you are a Communist if the Governor-General says you are.").

255. Defined as of May 5, 1950. Act No. 44 of 1950, $\$ 1(x v)$. "Communist party" includes every branch, section, affiliate, etc. Act No. 44 of 1950, $\S 2(1)$, as amended, Act No. 50 of $1951, \S 2$.

256. Act No. 44 of 1950, $\S 2(1) ; 3(1)$, as amended, Act No. 50 of $1951, \S 2$. 
and empowers the Governor-General to declare unlawful by notice in the Gazette any other organization if he is satisfied: that between May 5, 1950 and the effective date of the act it professed its purpose to be propagating the principles or promoting the spread of communism; or that its purpose was to spread or further the achievement of the objectives of communism; or that it engaged in activities calculated to further the achievement of any of the objectives of "communism" as defined ; or that it is controlled directly or indirectly by the communist party or any other unlawful organization. ${ }^{257}$

When an organization is declared unlawful, it loses both its property, which is vested in a liquidator named by the Minister of Justice, and its right to be registered; nor may any person be associated with or take part in any activity of or on behalf of the organization. ${ }^{258}$ The liquidator appointed by the Minister of Justice takes over the property, pays the organization's lawful debts, and distributes any balance remaining to scientific or charitable organizations designated by the Minister. ${ }^{259}$ The liquidator shall also, if directed by the Minister,

compile a list of persons who are or have been office-bearers, officers, members or active supporters of the organization which has been declared an unlawful organization: Provided that the name of a person shall not be included in any such list . . . unless he has been afforded a reasonable opportunity of showing that his name should not be included therein. ${ }^{200}$

If the Minister suspects that the purposes, activities, or control of any organization make it unlawful under the provisions of the act, he may designate an officer to investigate the organization. ${ }^{261}$

More serious consequences fall on the people whose names appear on the liquidator's list. The Minister may by written notice require any such person or a statutory communist or any person convicted of violating the act to comply with specified conditions as long as he is an office-bearer, officer, or member of any other organization or a member of any public body $;^{262}$ or he may be required to resign as or not to become an officer, office-bearer, or member of any organization ${ }^{263}$ or of any public body or not to hold public office $;^{264}$ and in certain cases such a person may be declared not to be a member of a public body, his seat being left vacant. ${ }^{265}$ As a saving provision, a per-

257. Act No. 44 of 1950, § 2(2). Trade associations and labor unions registered under the Industrial Conciliation Act are exempt under the definition. Act No. 44 of 1950, $\$ 2(3)$.

258. Act No. 44 of 1950, § 3(1).

259. Act No. 44 of $1950, \S 4(1)$-(4). If there is a deficit, he acts as a trustee in bankruptcy.

260. Act No. 44 of $1950, \S 4(10)$.

261. Act No. 44 of $1950, \$ 7$ (1) (a).

262. Act No. 44 of $1950, \S 5(1)$ (a). But the power to limit the activity of a trade association or any officer thereof shall not be exercised except in consultation with the Minister of Labor. Act No. 44 of $1950, \S 5$ (3).

263. Act No. 44 of $1950, \S 5(1)$ (b), (c).

264. Act No. 44 of 1950, $\$$ 5(1) (d), superseded by Act No. 50 of 1951, $\$ 4$ (a).

265. Act No. 44 of 1950, 5 (1) (e), (1) bis, added by Act No. 50 of 1951, $\$ 4(\mathrm{~b})$. 
son whose name appears incorrectly upon any list or whose name appears correctly but who proves that he did not and could not reasonably have been expected to know of the unlawful nature of the organization may have his name removed. ${ }^{206}$

But the restrictions imposed on individuals listed in connection with unlawful organizations are mild compared with the devastating limitations on freedom of movement and residence imposed on persons "banned" under the act:

Whenever the Minister is satisfied that any person is in any area advocating, advising, defending or encouraging the achievement of any of the objects of communism or any act or omission which is calculated to further the achievement of any such object, or is ... likely ... [to do so] $]^{267}$

he may by written notice prohibit him from being within any area defined in the notice; and any person so notified who fails to comply will be removed by the police. ${ }^{268}$

In addition, the Minister of Justice is given power to prohibit a particular assembly or the attendance of any specified person at a particular meeting or at all gatherings within a particular area or for a specified period. ${ }^{269}$

The penal provisions of the statute are extremely harsh. In addition to the more specific crimes defined in some detail, it is an offense to do any act calculated to further the achievements of or to advocate, advise, defend, or encourage communism as defined; to do various other acts forbidden by the statute; to fail to comply with its other requirements; or to hinder its application. Penalties for violation include up to ten years' imprisonment. 270 In addition, the act provides that a conviction for allowing premises to be used for certain unlawful purposes may result in its forfeiture to the state. ${ }^{271}$ The act provides immunity from defamation suits for calling a person a communist if he is named on any list prepared under the act or has professed to be a

266. Act No. 44 of 1950, $\$ 8(2)$. In discussing the Riotous Assemblies and Suppression of Communism Amendment Act, Act No. 15 of 1954, the Minister of Justice said that it was being provided, as to any person who protested to the courts against being listed, that in order to make it possible for us to prove that he had some connection with the Communist Party or with an illegal organization, ... documents, books, pamphlets, records and writings found in the possession of such an organization will be prima facie proof which will have to be accepted. We also say that photostatic copies of those things will be admissible in evidence....

H.A. Deb., Feb. 8, 1954, col. 267. Cf. Act No. 56 of 1955, § 263 bis, added by Act No. 9 of 1958 , \&3.

267. Act No. 44 of $1950, \S 10(1)$.

268. Act No. 44 of 1950, $\S 10(3)$. The Minister is permitted by statute to reimburse any person who is necessarily put to any expense as a result of such a notice. Act No. 44 of $1950, \S 10(2)$.

269. Act No. 44 of $1950, \S 9$.

270. Act No. 44 of $1950, \S 11$.

271. Act No. 44 of 1950, $\$ 13(1)$. But rights in such property of any person who did not know of such unlawful use are not affected. 
communist after the passage of the act or has been deemed a communist by the Governor-General or has been expelled from a public legislative body as a communist or has been convicted of certain offenses under the statute. ${ }^{272}$

Enforcement procedures under the statute are extremely rigorous. An officer investigating a suspected unlawful organization or publication may enter any premises at any time without notice and make such investigation and inquiry as he deems necessary; he may require the production of documents and seize them as evidence; he may question persons about the organization and may require anyone to appear before him and answer interrogations. ${ }^{273}$ In prosecutions under the act or in civil proceedings relating to its application when it is alleged that a person was a member or active supporter of any organization, on proof

that he attended any meeting of that organization, or has publicly advocated, advised, defended or encouraged the promotion of its purposes, or has distributed any periodical or other publication or document issued by, on behalf or at the instance of that organization, he shall be presumed, until the contrary is proved, to be or to have been a member or active supporter, as the case may be, of that organization..$^{274}$

The presumption as to convening a gathering is equally stringent. 275

An evaluation of the act after four years indicates that

Its sharpest hidden barbs ... seem to be directed against: ( $a$ ) the European members of Parliament who are the representatives and the official, but very vigorous, defenders of the natives; and (b) the nonEuropean leaders, who ... are in fact prevented from publicly expressing their opposition to any particular government measures and from trying to induce their hearers to share their views . . . . 276

The courts, however, have to some extent tempered the act's penal provisions by accepting interpretations favorable to the accused-at least in the case of

272. Act No. 44 of $1950, \S 17$ bis, added by Act No. 50 of $1951, \S 9$.

273. Act No. 44 of $1950, \S 7(3)$.

274. Act No. 44 of $1950, \S 12(1)$.

275. Act No. 44 of $1950, \S 12(2)$. But lack of knowledge of the prohibition of a gathering is a good defense. Act No. 44 of $1950, \S 12(3)$.

276. 1 U.N. Cosir'ss § 717.

Twenty African and Indian leaders in the defiance campaign [including Walter Sisulu, Secretary of the African National Congress, Nana Sita, president of the Transvaal Indian Congress, Maulvi I. A. Cachalia and $N$. Thandray, joint secretaries of the Transvaal Indian Congress] ... were convicted of ... "statutory Communism." ... Put on suspended sentence, they were prohibited from attending gatherings of more than three person for a period of two years; subsequently a number of Cape non-European leaders [including Robert Matji, secretary of the Cape African National Congress, and Dr. Njougwe, president of the Cape African National Congress] were similarly tried and sentenced. In 1953, a number of leading Africans were banned from membership in the African National Congress [including exChief Albert Luthuli, president-general of the African National Congress, Nelson Mandela, attorney and leader in the African National Congress, and Yusuf 
"named" as opposed to "actual" communists. ${ }^{277}$ Thus the Appellate Division has held ${ }^{278}$ that the Minister could not prohibit a person from attending gatherings in order to prevent the spread of communism without having in his possession facts on which he based his opinion and that hearing the individual was basic to obtaining the information under the fundamental RomanDutch principle of audi alteram partem; the conviction of the accused for attending a meeting from which he had been barred without a hearing was therefore held void. But Parliament promptly thereafter provided that no hearing would be necessary. ${ }^{270}$ Private social gatherings ${ }^{280}$ and any others, although public, at which it cannot be said that the participants had a common purpose, 281 have been held by the court not to be within the scope of an order prohibiting attendance at meetings. But meeting in advance with some directors of a public meeting and sitting afterwards in a car about 50 feet away with one's back to the public meeting while it was held was adjudged a violation of the statutory provision. ${ }^{282}$ The sentence of a perennial litigant was reduced upon evidence that he had attended a meeting in violation of an order upon advice of his counsel that his attendance would not constitute a crime. ${ }^{283}$

To cope with any stray subversive organizations not put out of operation by the Suppression of Communism Act-in particular the Pan-Africanist

Cachalio, joint honorary secretary of the South African Congress]. Few more effective means have been devised for limiting the growth and activities of organizations, at least in public.

CARTER 72-73. The names listed in brackets are taken from 2 U.N. Courar'N $\$ 198$. Luthuli has recently been awarded the Nobel Peace Prize for 1960. N.Y. Times, Oct. 24, 1961, p. 1, col. 2.

Also under the statute, "Solly" Sachs, president of the Garment Workers' Union, was forced to resign from the Union; and he ultimately left the country. Sam Kahn, a Natives' representative in the Assembly, and his successor, Brian Bunting, were expelled as communists; Fred Carneson was expelled from the Cape Provincial Council for the same reason. CArter 69-71.

277. But see Kahn v. Louw, N.O., [1951] 2 So. Afr. L.R. 194 (C).

278. R. v. Ngwevela, [1954] 1 So. Afr. L.R. 123 (AD).

279. Riotous Assemblies and Suppression of Communism Amendment Act, Act No. 15 of 1954, §§ 6, 7. See H.A. DEB., Feb. 8, 1954, cols. 264-66.

280. R. v. Kahn, [1955] 3 So. Afr. L.R. 177 (AD).

281. R.v. Mpeta, [1956] 4 So. Afr. L.R. 257 (C).

282. R. v. Lan, [1956] 2 So. Afr. L.R. 246 (AD). However, the court reduced the penalty to probation for a twenty-one year old first offender.

283. R. v. Sachs, [1953] 1 So. Afr. L.R. 392 (AD). One of the two justices who dissented from the modification of the sentence quoted Sachs' speech before the court in disgust, at 417:

It will be a sorry day for all the people of South Africa when the law becomes an instrument in the hands of tyrants instead of a shield to protect the liberty of the individual. ... The Act under which I have been charged and found guilty is named "Suppression of Communism." The "Suppression of Liberty" would be a more correct title. 
Congress and the South African National Congress ${ }^{284}$-Parliament enacted the Unlawful Organizations Act during the "emergency" in the spring of 1960.285 It empowers the Governor-General by proclamation to declare the two Congresses and all their branches and locals unlawful. ${ }^{286}$ In addition, he is empowered to outlaw any organizations which spring up under other names to take the place of the Congresses, and also any other organizations which in his opinion are trying to achieve the same purposes as any banned organization. ${ }^{287}$ Although no such proclamation may last more than 12 months, it may be renewed for successive periods of not more than 12 months. ${ }^{288}$

But the most dangerous provision potentially is one which "provides that certain machinery of the Suppression of Communism Act of 1950 shall apply in declaring these two organizations to be unlawful . ..."288 According to the

284. For a history of the two organizations and an analysis of their membership, aims, etc., see H. A. Deb., March 29, 1960, cols. 4302, 4318-19, and SEN. DeB., April 5, 1960, cols. 1781, 1840. The Minister of Justice charged :

[T] he fundamental aims of the A.N.C. [African National Congress], which is a multi-racial movement, are inter alia:

(1) The creation of a united nation out of the heterogeneous tribes of Africa;

(2) the freeing of Africa from foreign domination and foreign leadership. It is clear from the speeches of the A.N.C. leaders that this "freeing of Africa from foreign domination and foreign leadership" means that they want to establish a state free from White domination and White leadership....

H.A. DEB., March 29, 1960, cols. 4307-08.

285. Act No. 34 of 1960. For details, see N.Y. Times, March 31, 1960, p. 1, col. 8; id., April 10, 1960, p. 2, col. 1; id., April 23, 1960, p. 1, col. 7 ; id., June 26, 1960, sec. 1, p. 12, col. 1 .

286. Act No. 34 of $1960, \S 1(1)$.

287. Act No. 34 of $1960, \S 1(2)$.

A member of the opposition charged:

[W] hen one realizes that the hon. the Minister does not define the purpose, when one realizes that he does not define the objectives of these two organizations, one realizes how wide and how vast the net is being cast by the Government through this Bill.

H.A. DEB., March 29, 1960, col. 4337. But a government member said :

I support this Bill because it is very clear that these organizations which this Bill is now trying to ban have actually one main aim, one aim which one has found throughout the continent of Africa over the past years and that is to place South Africa in a condition of chaos by means of violence, violence against Europeans as well as non-Europeans, a condition of anarchy in which they can bring the White man to his knees. ...

SEN. DeB., April 5, 1960, col. 1796.

288. Act No. 34 of $1960, \S 1$ (3).

An opposition critic declared :

This is not an emergency Bill ... this is a Bill which is to impose in South Africa a new pattern of life. This is a Bill which gives to the hon. the Minister, for the first time, the right to ban political organizations. This is not an emergency measure. This is to be a new pattern of legislation in South Africa.

H.A. Deb., March 29, 1960, col. 4337.

289. Act No. 34 of $1960, \S 2$. The words are those of the Minister of Justice in H.A. DEB., March 29, 1960, col. 4304. 
Minister of Justice, the provisions which would be carried over include: special treatment for trade unions and their members; prohibition on membership in unlawful organizations; vesting of the property of unlawful organizations in a liquidator; authorization of the Minister to restrict any officebearer or member of an unlawful organization from belonging to other organizations or engaging in certain other activities; authorization of inquiries into the affairs of other organizations to determine if they are unlawful; and prescription of penalties. ${ }^{200}$ But an opposition member analyzed the same short section in the following manner:

May I refer to Clause 2 of the Bill, which ... says-

Any reference in the Suppression of Communism Act, 1950, to the objects of communism, shall be construed as a reference to the objects of an organization ... which is an unlawful organization in terms of a proclamation under sub-section (1) or (2) of Section 1 of this Act. That means that all reference to the objects of communism must be interpreted in the relevant section as applying to the objects of the Pan Africanist movement or the African National Congress. When one looks at Section 11 of the Suppression of Communism Act, which is one of the sections which is now to be applied to these two organizations, one finds

Any person who-

(o) performs any act which is calculated to further the achievement of any of the objects of communism ...

shall be guilty of an offence.

Now, that must be read when related to the Bill before us in the following terms-

Any person who performs any act which is calculated to further the achievement of any of the objects of the African National Congress or of the Pan Africanist movement, shall, be guilty of an offence.

That is ridiculously wide .... My party, the Progressive Party, wishes the

Pass Laws to be abolished, and that is one of the objects of both the

African National Congress and the Pan Africanist movement and, as soon as we advocate the abolition of the Pass Laws, we become guilty of an offence. 201

It may be noted that several of the defendants who were acquitted in the "treason trial" which finally ended in the spring of 1961, were immediately rearrested under the Unlawful Organizations Act. ${ }^{292}$

The third major statute in the triad restricting free association is the Riotous Assemblies Act, ${ }^{293}$ which prohibits many acts substantially the same as those

290. Id., cols. 4304-05.

291. H.A. DEB., March 30, 1960, cols. 4575-76. This was followed immediately by the following exchange:

Government member: Is that not a good idea? Opposition speaker: It is reactions such as those from the side opposite that make us worried about the terms of this Bill....

Id., col. 4576.

292. N.Y. Times, March 30, 1961, p. 1, col.7.

293. Act No. 17 of 1956, replacing an earlier act of the same name, Act No. 27 of 1914. 
forbidden by the Suppression of Communism Act, and in addition provides similar preventive measures.

The act empowers any magistrate to prohibit particular public gatherings in a public place if he has reason to apprehend that the public peace will be seriously endangered thereby $;^{294}$ and he may prohibit specified public gatherings, or any person from attending specified gatherings during a specified time period or in a specified area if he apprehends the engendering thereby of hostile feelings between Europeans and "any other section of the inhabitants of the Union."295 Any person who convenes, addresses, or prints notices of a prohibited meeting with knowledge of the prohibition or who attends after he has been prohibited is subject to criminal penalties. ${ }^{206}$ The magistrate may also order access to a public place closed in connection with the prohibition of an assembly, and he may close adjacent places as well. ${ }^{297}$ In addition, prohibited public meetings and meetings which become riotous in fact may be broken up. 298

The act empowers the Governor-General by notice in the Gazette to prohibit the publication or dissemination of any document containing information calculated to engender hostility between Europeans and "any other section of the inhabitants of the Union."299 Similarly, whenever the Minister of Justice is satisfied that any person is promoting feelings of hostility between Europeans and others, he may by written notice to the person prohibit him from being within any specified area for a stated period. ${ }^{300}$ In a famous case decided under the predecessor Riotous Assemblies Act, the Supreme Court refused to enjoin the Minister of Justice from prohibiting the petitioner from certain areas until he should specify the grounds on which the notice was based and give the petitioner a fair chance of reply:

294. Act No. 17 of 1956, § 2(1). Section 1 (iv) defines public gathering as "any gathering, concourse, or procession in, through, or along any public place, of twelve or more persons having a common purpose, whether such purpose be lawful or unlawful...."

295. Act No. 17 of $1956, \S 2(3)$.

296. Act No. 17 of 1956, § 2(4). Section 4 of the Unlawful Organizations Act substitutes the (heavier) penalties prescribed in $\$ 2$ of the Criminal Law Amendment Act, Act No. 8 of 1953 , for those formerly set out in this act.

297. Act No. 17 of $1956, \S 6$.

298. Act No. 17 of $1956, \S 7$. The common law crime of inciting to riot is committed, according to the definition in $\S 17$, by any one who

in any place whatever, ... has acted or conducted himself in such a manner, or has spoken or published such words, that it might reasonably be expected that the natural and probable consequences of his act, conduct, speech or publication would, under the circumstances, be the commission of public violence by members of the public generally or by persons in whose presence the act or conduct took place or to whom the speech or publication was addressed.

299. Act No. 17 of 1956, \& 3(1).

300. Act No. 17 of 1956, § 3(5). A person born outside the Union who violates any of the foregoing prohibitions may be deported and listed as a prohibited immigrant. Act No. 17 of $1956, \S 5$. 
Parliament may make any encroachment it chooses upon the life, liberty or property of any individual subject to its sway, and ... it is the function of courts of law to enforce its will. ${ }^{301}$

This is still the rule in South Africa, which inherits its tradition of Parliamentary supremacy from Britain, ${ }^{302}$ although the courts have frequently shown a disposition to think the best (for the individual) of Parliamentary intentions even when such thoughts were highly unrealistic and promptly repudiated by Parliament. ${ }^{\mathbf{0 3}}$

The last portion of the Riotous Assemblies Act deals with strikes and labor disputes. It prohibits intimidation or annoyance of persons to compel anyone to do or abstain from doing anything he has a legal right not to do or to do, particularly joining a "society or association." 304 It prohibits trespass on work premises to persuade workers to stop or refrain from starting work as well as the use of opprobrious epithets or conduct and blacklists. ${ }^{305}$ Finally, the act prohibits breach of an employment contract by a public utility worker

knowing or having reasonable cause to believe that the probable consequence of his so breaching such condition or contract will be to deprive the members of such community, or a large section thereof, wholly or to a great extent of their supply of light, power or water, or of sanitary or transportation services .... ${ }^{306}$

The cited provisions limiting public meetings and their attendance by particular persons are supplemented by more general restrictions on Africans found in the Urban Areas and Native Administration Acts. The former empowers the Minister by notice in the Gazette to

prohibit the holding of any meeting, assembly or gathering (including any social gathering), which is attended by any native, in any urban area outside a native residential area ... [and] by like notice [to] any person mentioned in the notice, or by notice in writing addressed to any person prohibit that person, from holding, organizing or arranging any such meeting, assembly or gathering ...

301. Sachs v. Minister of Justice, [1934] So. Afr. L.R. 11, 37 (AD).

302. Status of the Union Act, Act No. 69 of 1934; KenNedy \& ScHLosberg 83-91; McWhinney, The Union Parliament, the Supreme Court, and the 'Entrenched Clauses' of the South Africa Act, 30 CAN. B. Rev. 692 (1952) ; Pollak, The Legislative Competence of the Union Parliament, 48 S.A.L.J. 269 (1931).

303. McWhinney, Race Relations and the Courts in the Union of South Africa, 32 CAN. B. Rev. 44, 68-69 (1954).

304. Act No. 17 of 1956, $\S 10,11$.

305. Act No. 17 of 1956, $\$ \$ 12,13$.

306. Act No. 17 of 1956, $\S 14(1)$. An employee who maliciously breaks an employment contract with knowledge, or having reasonable cause to believe, that the consequences of such breach will be "to endanger human life or to cause serious bodily injury to, or serious injury to the health of, any person, or to expose valuable property ... to destruction or serious injury" shall be guilty of an offense. Act No. 17 of 1956, § 14(2). 
if in the Minister's opinion such meeting would cause a nuisance or be undesirable. $^{307}$ The latter act simply empowers the Governor-General to make regulations, inter alia, for the "prohibition, control or regulation of gatherings or assemblies of Natives" ; 308 under this authorization he has prohibited anyone from holding, presiding, or addressing, without permission from a native commissioner, any meeting, gathering, or assembly at which more than ten Africans are present at one time. ${ }^{300}$

In a number of criminal prosecutions for violation of the regulations issued under the two acts the courts have shown an inclination to interpret the regulations and statutes favorably to the defendant. An interracial meeting called by the Civil Liberties Defence Committee to protest treason arrests, at which approximately 50 Europeans, 150 Indians, and 200 Africans were present, was held not to be a "meeting of natives" within the meaning of the regulations. ${ }^{310}$ Similarly, a regulation which prohibited meetings "at which more than ten natives are present at the time" was adjudged ultra vires insofar as it would restrict interracial meetings. ${ }^{311}$ But another court upheld the same regulation as applied to an interracial meeting of about 100 coloreds and 16 Africans. ${ }^{312}$ A conviction under substantially the same regulation was reversed in a case ${ }^{313}$ in which an African, asked to address an (exempt) statutory body arrived after the meeting had officially adjourned but was asked to speak to those still present at the meeting place; the court, obviously disturbed at the Crown's attempt to punish the speaker, held lack of mens rea was a sufficient defense here.

If the foregoing laws are not sufficient to prevent effective opposition to the policies of apartheid, the Public Safety Act of 1953 provides that the GovernorGeneral may proclaim a state of emergency in the Union or any part thereof if any action or circumstances threaten public safety or order or if ordinary law is inadequate to ensure public safety and order. ${ }^{314}$ While such a proclamation is in effect, the Govenor-General ${ }^{315}$ may make any necessary or expedient regulations to provide for the public safety or to preserve public order and

307. Act No. 25 of 1945, $\S 9$ (7) (f), added by Act No. 36 of 1957, $\$ 29$ (d).

I repeat that mental conviction in politics is completely beyond the understanding of the ordinary Bantu ... who form a fertile field for inciters. ... [T] he leader who can produce a show of courage and action benefits far more thereby than if he were to rely upon the mental conviction of the Bantu. For this reason it would be fatal to permit large political meetings in Bantu areas....

SEN. DeB., March 30, 1960, col. 1565.

308. Act No. 38 of $1927, \S 27(1)$ (c).

309. Cf. R. v. Tanci, [1958] 4 So. Afr. L.R. 534 (T).

310. R. v. Mall, [1958] 3 So. Afr. L.R. 872 (N).

311. R. v. Tanci, [1958] 4 So. Afr. L.R. 534 (T).

312. R. v. Heyns, [1958] 2 So. Afr. L.R. 253 (ECD).

313. R. v. Tsotsi, [1956] 2 So. Afr. L.R. 782 (AD).

314. Act No. 3 of 1953, § 2(1). 4(1).

315. Or "owing to special circumstances," the Minister of Justice. Act No. 3 of 1953, § 
to terminate the emergency. ${ }^{316}$ The only limitations on this power are that compulsory military service shall not be imposed; penalties imposed for violation of the regulations are limited; no change shall be made as to elections, tenure of legislative officers, or sessions of Parliament; no lawful actions under the Industrial Conciliation Act shall be declared unlawful; and the detention of persons on summary arrest shall be reported to Parliament. ${ }^{317}$ No emergency proclamation shall remain in effect longer than 12 months, but a new order may be issued as to the same area at the expiration of a former one. ${ }^{318}$

In opposing the proposed Unlawful Organizations Act one M. P. claimed the Public Safety Act gave sufficient power:

The powers that the Public Safety Act gives to the Government are virtually limitless powers. Only once in British [sic] history have powers been comparable with those given by the Public Safety Act ... in 1539 ... the Statute of Proclamations .... . [T] he Public Safety Act of 1953 ... is an exact equivalent of the Statute of Proclamations of the reign of Henry VIII. In precisely the same way, under the Public Safety Act, there is a "virtual resignation of the essential character of Parliament as a legislative body"....310

Indeed, the emergency declared after the attempted assassination of Prime Minister Verwoerd in the spring of 1960 was declared under the Public Safety Act; and the regulations issued under it were so severe as to raise serious doubt at the time about the restoration of democratic liberties. ${ }^{320}$

\section{Control of Emigration and Immigration}

If severely restricting the franchise and right to free association of groups potentially dangerous to the Government is an effective way of ensuring the promulgation of apartheid policies, another way to weaken opposition is to prevent contact between dissidents within the Union and their sympathizers outside. To achieve this objective in the face of court decisions that the judiciary could look into the revocation of a passport ${ }^{321}$ and compel the return of one wrongfully withdrawn by the government, ${ }^{322}$ the Nationalists enacted the Departure from the Union Regulation Act in 1955, which vests complete control of passports in the government. ${ }^{323}$ This control has been

316. Act No. 3 of $1953, \S 3(1)$.

317. Act No. 3 of $1953, \S 3(3)$, (4).

318. Act No. 3 of 1953, § 2(2).

319. SEN. Deb., April 5, 1960, cols. 1809-10.

320. InT'L Comm'N App. A, F. Certain other statutes, such as the Defence Act, Act No. 44 of 1957, were also cited for particular powers (e.g., mobilization of citizen defense force).

321. Sachs v. Donges, [1959] 2 So. Afr. L.R. 265 (AD); Note, 32 J. CoMr. Leg. \& INT'L LAW (3d ser.) Pt. III, at 81 (1950).

322. Donges v. Dadoo, [1950] 2 So. Afr. L.R. 321 (AD).

323. Act No. 34 of $1955, \S 5(5)$. 
freely exercised to lift the passports of Alan Paton ${ }^{324}$ and Ronald Segal, ${ }^{325}$ among others.

But the Union not only controls the emigration of its own nationals; it also prohibits the inhabitants of South West Africa, the former German colony which it administers under its League of Nations mandate, ${ }^{326}$ from leaving the country, even when they have been invited by the UN to testify before it. ${ }^{327}$

As to immigration, the Union not only exercises its sovereign power to exclude individuals at will, without explanation, but also bars large groups by statute for reasons of race. No group has suffered more from such legislation than the relatives and friends of Indians in the the Union who have sought to join them there. The first laws restricting Indian immigration were passed by the Boer colonies soon after the first Indians arrived in Natal, ${ }^{328}$ and there has been a constant stream of such legislation ever since. ${ }^{320}$ Although the courts have not been particularly sympathetic, except to close relatives thwarted by rigid administration of the law, a survey of recent Law Reports shows that this attitude has not ended recourse to the judiciary for relief of Indian deportees. ${ }^{\mathbf{8 3 0}}$

\section{Repressive Aspects of the Administration of Criminal Law}

The restrictive network of statutes designed for promulgating apartheid policies is given teeth by repressive measures built into the administration of criminal justice. The Criminal Law Amendment Act, passed when whites and Africans had joined in a non-violent defiance campaign against apartheid laws, provides extraordinary penalties for resistance to apartheid statutes. ${ }^{331}$ Anyone convicted of an offense

committed by way of protest or in support of any campaign against any law or in support of any campaign for the repeal or modification of any law or the variation or limitation of the application or administration of any law

324. N.Y. Times, Dec. 6,1960 , p. 14, col. 5 .

325. Africa South, Oct.-Dec. 1959, p. 1.

326. InT'L Conm'N 83-87. The Union refused to place the territory under the UN's trusteeship system, the only mandatory power to so refuse.

327. E.g., Chief Hosea Kutako, Jariretundu Kozonguizi. See 5 Arr. Dig. 154 (1958); H.A. DEB., March 30, 1960, col. 4534.

328. HANDBOOK 206.

329. E.g., Immigrants Regulation Act, Act No. 22 of 1913 ; Indians' Relief Act, Act No. 22 of 1914; Immigration and Indian Relief (Further Provision) Act, Act No. 37 of 1927.

330. See, e.g., Minister of the Interior v. Ebrahin, [1950] 1 So. Afr. L.R. 54 (T); Principal Immigration Officer v. Brey, [1950] 4 So. Afr. L.R. 207 (G) ; Latiefa v. Principal Immigration Officer, [1951] 2 So. Afr. L.R. 589 (C) ; Harneker v. Gaol Superintendent, [1951] 3 So. Afr. L.R. 430 (C) ; Donges, N.O., v. Bhana, [1953] 1 So. Afr. L.R. 30 (T); Sarahbibi v. Principal Immigration Officer, [1957] 2 So. Afr. L.R. 175 (N).

331. Act No. 8 of 1953. 
may be sentenced to a fine of $£ 300$, three years imprisonment, 10 strokes, or a combination of any two of them. ${ }^{332}$ A person who advises, encourages, incites, commands, aids, or procures anyone to commit a crime by way of offense against a law or in support of a defiance campaign shall be subject to a fine of $£ 500$, five years imprisonment, 10 strokes, or any two of these; and for a second offense imprisonment or whipping must be imposed in addition to a fine. . $^{333}$ Similarly, any person who solicits or receives assistance for any such campaign or who has assisted another to commit a crime by way of protest shall be penalized as for incitement. ${ }^{334}$ A person convicted for violating any of these provisions may by notice from the Minister of Justice be prohibited from being in any area. ${ }^{335}$

In prosecuting crimes under this statute, it is presumed, unless the contrary is proved, that if a person is charged with an offense committed by way of protest, and the alleged offense was committed in the company of two or more persons who have been or are charged with committing similar offenses at the same place and time, the offense was committed as alleged. ${ }^{336}$ Persons charged with committing the same offense under this act at substantially the same time and place may be tried jointly regardless of the provisions of any other law. ${ }^{337}$

So far the hierarchy of the Anglican Church, which has authorized the bold notice on its Johannesburg cathedral that all persons are welcome to worship inside, has not yet felt the force of the law for this action, but there is no assurance that the cloth will indefinitely protect its wearers. The effect of the Suppression of Communism, Public Safety, and Criminal Law Amendment Acts read together

certainly will be to make it much more difficult than before for non-White organizers to launch any concerted campaign of resistance against the laws, and even to prevent non-European leaders stating their opposition to a bill introduced by the Government or criticizing it. . $^{338}$

To ensure that these measures achieve their desired objectives, the government has built up a battery of powers for their enforcement. Among the most shocking is the virtually unlimited right of search and seizure written into myriad individual statutes in substantially the following terms :

Any inspector may, without previous notice, at any time enter any premises whatsoever and may ... question any person who is or has been upon or in the premises ... and may require ... the production then and

332. Act No. 8 of $1953, \S 1$.

333. Act No. 8 of $1953, \S 2$.

334. Act No. 8 of 1953, $\S 3(1)$. But see R. v. Moshoe, [1953] 4 So. Afr. L.R. 119 (T).

335. Act No. 8 of $1953, \S 9(1)$.

336. Act No. 8 of $1953, \S 4$.

337. Act No. 8 of $1953, \S 5$.

338. 1 U.N. CoNA'N $\$ 720$. 
there ... of all books and documents ... and may seize any such books or documents .... 339

Most general powers are, however, set forth in the Criminal Procedure Act of $1955 .^{340} \mathrm{It}$ permits the police to search persons, premises, or vehicles without a warrant if they believe that the delay involved in obtaining a warrant would defeat the object of the search. ${ }^{341}$ As a "safeguard," the search may be only for (a) stolen property or property in relation to which an offense is suspected to have been committed anywhere; (b) anything which there are reasonable grounds to believe will afford evidence of the commission of a crime somewhere; or (c) anything in respect to which there are reasonable grounds to believe that it is intended to be used to commit an offense. ${ }^{342}$

Far more important to the opposition is the provision that if it appears to a judge or magistrate that there are reasonable grounds for believing

that the internal security of the Union or the maintenance of law and order is likely to be endangered by or in consequence of any meeting which is being or is about to be held in or upon any premises ... . [or] that an offence has been or is being or is likely to be committed or that preparations or arrangements for the commission of any offence are being or are likely to be made... [in certain premises, he may issue a warrant to enter and search and to take] such reasonable steps as [such policeman] ... may consider necessary for the preservation of the internal security of the Union or the maintenance of law and order, or for the prevention of the commission of any offence . . . ${ }^{343}$

And if a police officer believes that the delay involved in obtaining a warrant would defeat its objects, he may enter without a warrant and "... [carry] out such investigations and ... [take] such reasonable steps as ... [he] may consider necessary for that preservation of the internal security of the Union or the maintenance of law and order ..." or search the premises for evidence of an offence. ${ }^{344}$

339. Native Labour (Settlement of Disputes) Act, Act No. 48 of 1953, § 19(4). See also Group Areas Amendment Act, Act No. 77 of 1957, § 39(2); Industrial Conciliation Act, Act No. 28 of 1956, § 61 (1) ; Native Building Workers Act, Act No. 27 of 1951, § 26(1); Wage Act, Act No. 44 of 1937, $\$ 27(1)$; Arms and Ammunition Act, Act No. 28 of 1937, $\S 33$.

340. Act No. 56 of 1955.

341. Act No. 56 of $1955, \S 43(1)$. Objects seized shall be taken before a magistrate.

342. Act No. 56 of $1955, \S 42(1)$. Under $\S 46(1)$ the police may enter and search any premises at any time for stolen stock or produce or articles possessed in contravention of the laws governing intoxicating liquor, habit-forming drugs, arms and ammunitions, or explosives.

343. Act No. 56 of $1955, \S 44(1)$.

344. Act No. 56 of $1955, \S 44(1)$.

Two prominent South Africans, commenting on the significance of the first part of this section, have declared:

[T] he legislature has now authorized police intrusion into private premises, when no reasonable belief exists that any offence has been or is being, or is likely to be, committed by those present or by anyone else for whose acts those present at the 
Under this statute many of the persons detained during the emergency of spring 1960 were arrested in their homes at 2 a.m., an old South African custom, as the Minister of Justice admitted to the laughter of the House. ${ }^{345}$ And quite possibly under this statute the government assumes the authority surreptitiously to open the mail of suspected opponents, ${ }^{346}$ to search, seize and retain the baggage (taken from locked car trunks) of foreign visitors of whom it is suspicious, ${ }^{347}$ and to tap the telephones of political opponents. ${ }^{348}$

The act also empowers the Minister of Justice to direct trial without jury of a number of offenses, including certain crimes defined by the Riotous Assemblies Act and any crime against or in connection with a white if any defendant is nonwhite or against or in connection with a nonwhite if any defendant is white. ${ }^{349}$ When the Attorney General indicts anyone for treason, sedition, public violence, or attempt, conspiracy, or incitement to any of the same and "is of opinion that, if the accused were tried by a jury, the ends of justice are likely to be defeated," the Governor-General may constitute a special criminal court to try such offense without a jury. ${ }^{350}$ Such court shall consist of two or three justices of the Supreme Court, whose decision must be unanimous. ${ }^{351}$ The recent "treason trial" in 1956 of opponents of apartheid was brought before such a tribunal. ${ }^{352}$

The "treason trial" is characteristic of South African justice, which has apparently turned increasingly toward mass criminal trials. ${ }^{353}$ There are two particularly unfortunate aspects of such trials. "First, they tend to shift the

meeting can be held legally responsible; further ... this is so when no reasonable belief exists that preparations for an offence are being, or are likely to be, made at the meeting. The right to intrude is given, it appears, solely because what is thought will be said or done at the meeting, albeit completely lawful in character, is likely to endanger the internal security of the Union or to have that consequence.

Brookes \& MACAULAY 35.

345. H.A. Deв., March 30, 1960, col. 4439; the Minister of Bantu Education, replying to the criticism, noted that when the critic had been Minister of Justice "he caused hundreds of persons to be arrested in South Africa at two or three o'clock in the morning and in the middle of the night...." Id., col. 4446.

It may be noted that many of the "treason trial" defendants were arrested at about the same hour by police officers already in their bedrooms when they awakened.

346. Reported by numerous South Africans, including Bishop Reeves, now refused reentry into the Union.

47. Reported by Allard Lowenstein, who reported on other aspects of his journey in the Union and South West Africa to the United Nations' Trusteeship Committee.

348. Reported by South Africans who state that it is not unusual for censors to interrupt telephone conversations and argue with the speakers!

349. Act No. 56 of $1955, \S 111$.

350. Act No. 56 of 1955, §§ 112(1), (2).

351. Act No. 56 of $1955, \S 112(3)$ (a).

352. It should be noted that the defendants managed to get one judge to recuse himself due to his connection with the proceedings at an earlier stage. N.Y. Times, Aug. 5, 1958, p. 12 , col. 4 .

353. Int'L Comm'n 62; Fairbairn, Mass Trials, Africa South, April-June 1959, p. 12. 
weight of repressive law from the political ringleaders to the rank and file of any political resistance movement"; second, "they constitute a great burden on the accused and their families ...."354 Costs are rarely awarded against the prosecution in South Africa, and legal aid is almost non-existent. ${ }^{\text {sit }}$ And, as a matter of course, no way has ever been devised to conduct such mass trials so that the rights of every individual defendant can be fairly protected.

To curb the independence of the bar, which has rendered heroic service in defending political opponents of the regime, a bill has been proposed to give the government complete control over the admission, suspension, and disbarment of advocates (barristers) ${ }^{356}$ This measure is reported to have been circulated among the bar for its consideration, and apprehension has been aroused by the lack of definite standards for admission and disbarment.

\section{Restrictions on Freedom of Speech and Press}

Restrictions on the franchise, association, and movement would, however, hardly preserve apartheid against a determined opposition without control of speech and press. The results of such control may be somewhat less tangible, but they are nonetheless effective ; a public which cannot readily learn of the existence or views of the opposition or of the views or news of the outside world may perhaps be conditioned to believe in the futility and fatuity of resistance. As a consequence the government has enacted numerous restrictions on speech and press, many of which are largely duplicitous, and it appears eager to increase further its armory of powers.

In order to suppress "communism," the Governor-General is empowered, with no notice other than proclamation in the Gazette, to prohibit the printing, publication, or dissemination of any periodical or other publication which he is satisfied is published or disseminated by an unlawful organization or expresses the views of such an organization or furthers "communism."358 A person who thereafter publishes or disseminates such a periodical or publication is guilty of an offense. ${ }^{\mathbf{s 5}}$

To prevent incitement of Africans, the Native Administration Act of 1927 provides that "any person who utters any words or does any other act or

354. INT'L COAMN'N 62.

355. Ibid.; cf. Hayman, Legal Aid for the Poor in South Africa, 26 J. CoMr. LEG. \& INT. L. (3d ser.) Pt. III, at 12 (1944). Hundreds of thousands of pounds were raised overseas and many in South Africa to pay legal expenses of the treason trial defendants and to succor the families of the accused. The attorneys who represented the accused gave up years of their time to serve at a fraction of their ordinary fees, according to Bishop Reeves, a trustee of the special relief fund.

356. Int's Comm'N App. A, 109.

357. Ibid.

358. Act No. 44 of $1950, \S 6$.

359. Act No. 44 of 1950, § 11(d). If the Governor-General believes that any periodical or publication ought to be prohibited, he may appoint an investigator to look into the question. Act No. 44 of 1950, § 7(1) (b). 
thing whatever with intent to promote any feeling of hostility between Natives and Europeans shall be guilty of an offense."360 A number of cases have arisen under this provision, but the courts have been loath to muzzle free speech or press by finding the intent necessary to sustain conviction. In $R$. v. Sutherland, ${ }^{301}$ the joint defendants were the Sunday Express, its manager and a cartoonist. The offending cartoon showed two Africans, representing the British protectorates, facing Dr. Malan (then Prime Minister), who stood in the doorway of a room representing the Union, while behind him, in the room, a European was throttling a terrified looking African: The caption read, "Won't you come in?" The court found that there were many possible explanations of the cartoon $;^{302}$ since any of these would warrant an acquittal and the Crown had failed to prove that none of these represented the true intent, the prosecution failed to establish its case. In another case ${ }^{363}$ the offense was allegedly committed in a series of speeches admittedly incompetently reported by the police stenographer. Some of the more lurid passages included: "The cure for a mad dog is a knobkerrie. That is the medicine that has to be administered to these fellows ...." "We have not the power of the vote in this country. The only way we can change the state of affairs in this country is to have a revolution and that means bloodshed ...." "Some of the people in this country are not oppressors but the majority of them are not fit to live...." The court reversed the conviction in the lower court on the grounds that various inferences could be drawn from the speeches and that the speeches didn't lead to hostility against whites as a race, but merely against specified whites and those in authority, while expressing political grievances and asking for equality.

Perhaps as a consequence of these anti-government decisions, new and more drastic regulations were issued to ban "subversive" publications when the "emergency" was declared in the spring of $1960 .{ }^{364}$ Under these regulations a "subversive" statement was defined inter alia as one calculated or likely to have the effect of subverting the authority of the government, of inciting any person or class to resist or oppose the government as to the maintenance of public order or the application of the emergency regulations, of engendering or aggravating feelings of hostility towards any person, class, or section of the public, or of causing panic, alarm or fear or of weakening confidence in any section of the public in the successful termination of the state of emergency; dissemination of a subversive statement was made a crime. ${ }^{365}$

Far more serious, due to its non-emergency nature, is the proposed Publications and Entertainments Bill. ${ }^{306}$ Going beyond the proposals made by a

360. Act No. 44 of $1950, \S 29(1)$.

361. [1959] 4 So. Afr. L.R. 66 (T).

362. E.g., a protest against brutality generally or against oppression of the natives specifically, or against the fatuity of Malan's inviting the protectorates to join the Union.

363. R. v. Nkatla, [1959] 1 So. Afr. L.R. 26 (C).

364. Cited in INT'L Consm's 71.

365. Ibid.

366. Cited in INT'L Cons's 72. 
government commission in $1957,,^{367}$ it calls for pre-censorship of all books and periodicals by a Publications Board to be established by the Minister of the Interior. The Board is to refuse approval for any book, periodical, or film which "in its opinion is indecent, obscene or on any ground objectionable." It may also prohibit printing or publication of any book that is "undesirable," "undesirable" being anything which

(a) prejudicially affects the security of the state;

(b) can have the effect of -

(i) disturbing the peace or good order;

(ii) prejudicing the general welfare;...

(v) bringing any section of the inhabitants of the Union into ridicule or contempt;

(vi) harming relations between any sections of the inhabitants of the Union;...

(d) is otherwise on any grounds objectionable. ${ }^{369}$

Publication of "undesirable" newspapers is also prohibited, but control is vested in the courts. The courts may, however, consult the Publications Board as to its opinion whether any newspaper is "undesirable." The proposed statute grants broad powers of search and seizure and limits appeal from a decision of the Publications Board to a special administrative Appeal Board. whose decision shall be final. ${ }^{370}$

This bill has aroused the entire English press and even caused the Afrikaans newspapers to call for some backtracking. ${ }^{371}$ Foreign as well as South African publishers have expressed doubts whether they will continue in business in the Union if the bill becomes law in the form in which it was drafted..$^{372}$

Rigorous censorship has also been extended to foreign publications-thus complementing restrictions on immigration and emigration in isolating potential opposition from the influence of foreign ideas. The 1955 Customs Act bans "indecent, objectionable, or obscene" literature, ${ }^{373}$ and in issue after issue of the Gazette books are listed which it is illegal to import, possess, or deal in. An analysis of three proclamations issued within a half year ${ }^{\mathbf{3 7 4}}$ indicates that most of the prohibited books fall into one of three broad categories: (1) Generally obscene or indecent (sexually or anti-Christian), such as O'Hara, Butterfield Eight; Eves de Paris (French girlie magazine); Pearl, Girl with the Swansdown Seat; Russell, Why I Am Not a Christian; Havil, Birth Control and You; (2) racial, as Abrahams, Tell Freedom; Hatch,

367. See Hepple, The Undesirable Censorship Plan, The Forum, Nov. 1957, p. 11, For the history and effect of the Commission, see Hrpple, CENsorship and Press Contror in Soutr AFrICA 50-56 (1960).

368. INT'L COMM'N 71.

369. Ibid.

370. Id. at 72-73.

371. Id. at 72 .

372. Private conversations with publishers.

373. Act No. 55 of 1955, §21(1) (f).

374. So. Afr. Gazette, Dec. 19, 1958, p. 10 ; id., April 10, 1959, p. 6; id., July 25, 1959, p. 8. 
Dwell Together in Unity; Dollard, Class and Caste in a Southern Town; O'Neal, Conquests of Tamerlane; Wright, Uncle Tom's Children; and (3) political, as Kuper, Passive Resistance in South Africa; Sachs and Forman, The South African Treason Trial; Brailsford, How the Soviets Work; and Peking Review. ${ }^{375}$

\section{Restrictions on Education}

If restrictions on free speech and press take their most obvious form in outright censorship, their most insidious form is reflected in governmental techniques of controlling education. Within five years of their first electoral triumph the Nationalists enacted the Bantu Education Act ${ }^{376}$ to effect just such control.

At the time that act was passed, education of nonwhite children in the Union was a hit-or-miss affair, with the government running 992 schools for Africans while church missions, usually state assisted, ${ }^{377}$ had a school system of almost 900,000 children in nearly 6,000 schools, built almost entirely by voluntary effort, with most teachers trained at mission institutions. ${ }^{378}$ Nevertheless, only slightly more than $40 \%$ of the African children were in school, for education for Africans was free but not compulsory. ${ }^{379}$ All schools were segregated, although much earlier children of all races had gone to school together in the Cape and Natal. ${ }^{380}$ All nonwhite children who attended mission schools had been brought to some extent into the western cultural tradition, but there were vast differences, both from mission to mission and particularly between schools of the English-speaking churches and those of the Dutch churches. The former tended to give a European type academic education in the English language while the latter tended toward vocational training in the verna-

375. Bonjour Tristesse, by Sagan, was added by proclamation in the So. Afr. Gazette, July 25,1959, p. 8 , and deleted by Notice 1407 , Sept. 16, 1959, p. 13. And Black Beauty is said to have been banned because the censor did not understand that the protagonist is a horsel The Two Faces of Terror, Africa South, Jan.-March 1960, p. 3. For a short discussion with lists of banned publications, see HePple, Censorship and Press Control in South Africa 36-41 (1960).

376. Act No. 47 of 1953.

377. The Union government had taken over the financial aid previously given by the provincial governments to the private schools in which the vast majority of nonwhite children were educated. CARTER 100.

378. Macquarrie, The New Order in Bantu Education, Africa South, Oct.-Dec. 1956, p. 34; CARTER 100-01.

379. Carter 100-01 ; Reeves, Church and State in South Africa, Africa South, Oct.-Dec. 1956, p. 10; Macquarrie, supra note 378 . In the reserves only twenty-five percent of the African children were in school. Davie, Education and Race Relations in Soutr Africa 13 (1955).

1 U.N. Comm'N $\$ 696$ indicates that, although not free, education of Africans was developing rapidly. See, e.g., Cape and Orange Free State provincial legislation summarized in 29 J. CoMrp. Leg. \& INr. L. (3d ser.) Pt. I, at 110, 111 (1947).

380. Carter 100; HandBook 349-50; 1 U.N. Comarn § 695. 
cular with emphasis on tribal tradition. ${ }^{381}$ The government spent an average of $£ 43.88$ per year for primary education for each European child, $£ 18 . S+$ for each Asian and colored child, and $£ 7.58$ for each African child. ${ }^{382}$ African children were academically far behind their white contemporaries. ${ }^{383}$

During the same period the standards and curricula of all secondary schools were the same, regardless of race. ${ }^{384}$ But in 1946 only 22,015 African students attended high school; poverty was the primary cause of such limited secondary study. ${ }^{385}$

Before the government started to modify the educational system for Africans, it established the so-called Eiselen Commission to report on the proper goals to be achieved. ${ }^{386}$ The Commission report in many respects sanctified and gave official status to the proposals made in 1948 by the Institute for Christian National Education, whose policy-making members included leading Afrikaners. ${ }^{387}$ According to the Institute,

Native education should be based on the principles of trusteeship, nonequality and segregation; its aim should be to inculcate the white man's view of life, especially that of the Boer nation, which is the senior trustee. $^{388}$

The spirit of all teaching must be Christian-nationalist; in no subject may anti-Christian or non-Christian or anti-nationalist or non-nationalist propaganda be made. ${ }^{380}$

381. HANDBooK 348; 1 U.N. CoMrar'N $\S 694$.

382. CARTER 101.

383. The examinations reveal that the children of the Native schools are at least two years behind European children of equivalent ages both in the knowledge they have acquired and in their intellectual development....

1 U.N. Comm's $\$ 700$. Carter states that one-half of all African children are in substandard grades while one-fifth of all white children are; four percent of all African children go beyond the primary grades while 24\% of all European children do. CARTER 101.

Among the causes for the differential are: tribal responsibilities (such as cattle herding), lack of home background, inadequate textbooks, and language difficulties. CARTER 101; 1 U.N. COMIM'N $\$ \S 699,700$.

384. 1 U.N. COMM'N § 702.

385. Id., § 701.

386. It has been generally acknowledged in the Union that African education was inadequate in many respects and needed far more order and coordination. Thus there was general approval when the Nationalist Government appointed a distinguished Commission on Native Education in 1949 under the chairmanship of Dr. W. M. Eiselen, Secretary for Native Affairs....

CARTER 102.

387. Including Dr. E. G. Jansen (subsequently Governor-General) and Dr. T. E. Donges (Minister of the Interior). The Grave of the Mind, Africa South, Jan.-March 1957, p. 1.

388. Id. at 4, citing Art. 15 of the Christian National Education pamphlet.

389. Id. at 5, citing Art. 6(i) of the Christian National Education pamphlet.

Christianity was defined by the Institute as "the creeds of the three Afrikaner churches." $I d$. at 1, citing Art. 1. These are the three branches of the Dutch Reformed Church in South Africa. 
Building on this background, the Eiselen Commission called for the teaching of English and Afrikaans

in such a way that the Bantu child will be able to find his way in European communities, to follow oral or written instructions; and to carry on a simple conversation with Europeans about his work and other subjects of common interest. ${ }^{300}$ Your Commission recommends that handwork in the first four years of school should aim at the establishment of the habit of doing manual work. ${ }^{391}$

The Bantu Education Act was based on the Eiselen Commission recommendations. ${ }^{382}$ Under the act control of African education was transferred from the provinces to the Department of Native Affairs of the central government. $^{303}$ All schools so transferred were classified as: (1) Bantu (community) schools; or (2) government Bantu Schools; or (3) other (private and mission) schools. ${ }^{394}$ The first type consists of schools which are or will be controlled progressively in some way by African communities or Bantu authorities. . $^{305}$ These schools, which may obtain state subsidies, are the favored type, into which the government intends to transform all others in time. ${ }^{300}$ Government Bantu schools include the former provincial schools transferred to the Union government. ${ }^{397}$

390. Id. at 4, citing $\llbracket 924$ of the Christian National Education pamphlet.

391. Id. at 4, citing $\int 932$ (c) of the Christian National Education pamphlet.

392. Act No. 47 of 1953.

The Native Education Commission Report incorporated major criticisms of the existing system of African education. It declared that African education was not "an integral part of a plan of socio-economic development" of the Bantu people; that it was carried on without the active participation of the Africans as a people, either in their local communities or more widely; that its present financing made planning virtually impossible, and asked almost nothing directly from the Bantu people themselves....

CARTER 102.

393. Act No. 47 of $1953, \S 3(1)$. The education of colored children has been transferred to the Department of Coloured Affairs. Control of higher education was excepted from the act under $\$ 1$ (iii).

394. Act No. 47 of $1953, \S \S 6-8$.

395. H.A. DEB., Sept. 17, 1953, col. 3588.

396. Hon. members must remember that ... when the Act came into operation it was stated very clearly that the system of community schools was the desired system for Bantu education and that that was the aim of the whole system, and that those State Bantu schools which remained (whether they were aided Native schools or non-subsidized private schools) were remnants of the past and would disappear in the course of time....

H.A. DeB., April 24, 1956, col. 4282 (Minister of Native Affairs).

The Opposition now comes with the statement and the arguments that we want to oppress and destroy mission schools, private schools, and schools of all kinds except Government schools. As far as I am personally concerned, I welcome that heartily. ... H.A. DEB., April 24, 1956, col. 4276 (government member).

397. H.A. DEB., Sept. 17, 1953, col. 3589. 
The central government has already introduced changes in the curricu$\operatorname{lum}^{398}$ and teaching standards. Considerably more emphasis is now put on instruction in the mother tongue, although proficiency in both official languages is required for promotion-the most serious stumbling block of all for the average African child. ${ }^{399}$ Increased time is devoted to religion. ${ }^{400}$ To enable more children to attend school, lower grades and their teachers have been put on double sessions (three hours instead of four per session). ${ }^{401}$ Minimum standards for teachers of African children have been lowered from a Junior Certificate combined with two years of teacher training to Standard VI education plus three years of training. ${ }^{402}$

Another serious blow to African education resulted from the decision in 1954 that henceforth the Treasury would contribute only a fixed sum, $£ 6,500,000$, annually to the "Bantu schools," and that all other money must be raised from the African community itself. ${ }^{403}$ This curtailment on government grants to African education caused the termination of the subsidized lunch program in order to conserve money for education ${ }^{404}$ _but in view of general

398. E.g., grouping together history, geography, and civics as "environmental studies." CARTER 108.

399. DAVIE, op. cit. supra note 379, at 14-15; Macquarrie, supra note 378, at 41.

400. CARTER 108. A standardized Christian religion is taught, presumably as set forth in syllabi prepared by Afrikaans religionists. An opposition M.P. noted that in the Transvaal Catholic priests who administered farm schools were instructed in, "the neutral syllabus of basic Christianity," and a government supporter responded that "if there are 20 churches, then surely we cannot possibly have 20 types of religious instruction in a school. ..." H.A. DeB., April 17, 1956, cols. 3774, 3777.

401. CARTER 106; DAVIE, op. cit. supra note 379, at 14. In defending the introduction of double sessions without additional pay for the teachers, the then Minister of Native Affairs, now Prime Minister, stated :

[I]n practice ... these double sessions only relate to the very lowest classes where the teacher has comparatively little work after school hours.... In other words in the past such a teacher took classes for only four and a half hours really. With the introduction of the double session the teacher is occupied in class for six hours per day, three hours for one section and three hours for the other section. I do not think it is too much to expect ... without receiving additional over-time salary. There is nothing wrong with it.

H.A. DEB., June 11, 1957, col. 7792 .

402. Macquarrie, supra note 378, at 39. Teachers of European children must possess a Senior Certificate plus two years' professional training as a minimum. Ibid.

403. Carter 106.

Funds traditionally available from the Bantu community have included four-fifths of the general tax levied on Africans, and other limited, miscellaneous revenues. Exchequer and Audit Amendment Act, Act No. 7 of 1955, $\S 1$.

404. H.A. DeB., June 11, 1957, cols. 7775, 7777, 7782.

As of about 1946, "supplementary" meals for white, colored and Asian children were subsidized at $3 \mathrm{~d}$. per child per day and full meals at $6 \mathrm{~d}$. per child per day; meals were subsidized at $2 \mathrm{~d}$. per day per child for Africans. HAxdBoor 433. 
African poverty it was a bitter choice to make.405 Increased taxes on the poverty-stricken Africans seem inevitable. ${ }^{406}$

But in many ways these changes are only symptoms of a more fundamental reorientation in the spirit behind African education. ${ }^{407}$ The special UN Commission has charged that the Bantu Education Act is only too effectively realizing the objectives of the Eiselen Commission:

It is clear that the aim of the Act is to give the African an inferior kind of education so as to keep him permanently as a hewer of wood and a drawer of water.... 408

And the present Prime Minister, then Minister of Native Affairs himself confirmed this charge obliquely:

Racial relations ... cannot improve if the result of Native education is the creation of frustrated people who, as a result of the education they received, have expectations in life which circumstances in South Africa do not allow to be fulfilled . . . .409

405. To many Afrikaners the termination of the program was welcome for reasons strangely reminiscent of those expressed years ago by opponents of school lunches in this country :

[T] he Bantu children have not enjoyed the benefits of the feeding scheme .... Most of the food supplied was simply wasted. At several schools which I visited I found that ... the food ... was put aside in a little room, and there I saw the fattest mice I have ever seen anywhere. The mice were fat and the children were thin....

The other important phenomenon ... in these schools was this: A large number of those children left home hungry when they went to school because the parents had been told that the children would be given a meal at school... . The people who must regret the fact that the feeding scheme is now to be abolished are not the Bantu parents or the Bantu children but the white merchants....

H.A. DEB., June 11, 1957, col. 7799.

406. The parents of the Bantu children should not be excluded from co-responsibility for the education their children are to receive, and that co-responsibility is twofoldit is co-responsibility for control, but associated with that is co-responsibility in respect of finances. the [sic] Native parent will have to have a share in the financing of Native education....

H.A. DEB., Sept. 17, 1953, col. 3581 (Minister of Native Affairs).

407. Carter 102-03.

408. 2 U.N. CoMm'N $\$ 161$, citing a memorandum submitted by the African National Congress and the South African Indian Congress. Another commentator has stated:

There can be little doubt that it is the intention of the framers of the Act that the education of the African child shall be different from that of the European and, further, that this difference shall establish and perpetuate an inferior status in the African in relation to the European. The education of the child is therefore not intended to stimulate the development of its intellect and character, but to prepare it for a certain service to the state; a service which is primarily that of servant of the Europeans and secondarily one which carries with it no promise of advancement towards the eventual social and political status which he covets in order to benefit to the full under western democracy.

DAvIE, op. cit. supra note 379 , at 15-16.

409. H.A. DEB., Sept. 17, 1953, col. 3576. 
In no way does the spirit of the new African education show up more clearly than in the new rigid control of African schools. "Academic freedom" is unknown for teachers of African pupils. Criticism of government policy in relation to racial matters constitutes misconduct, to which the standard penalties are applicable. ${ }^{40}$ In addition, grants-in-aid to all Bantu schools are paid in respect of each post and each incumbent of each post-i.e., the subsidy itself controls the individual; and while the regulations governing penalties for misconduct require notice and hearing, the refusal of a subsidy is absolutely discretionary with the Department, with no procedural protection to the individual or to the employing school. ${ }^{411}$ Indeed, the government has sometimes been unwilling to settle merely for dismissal from office but has continued by all means at its disposal to persecute an ex-teacher who has opposed official policy. ${ }^{412}$

Pupils are protected against noxious written words as well as radical teachers. Thus the books and periodicals which may be bought or kept for school libraries are carefully specified. All others have to be approved, and a teacher may not even lend his own book or publication to a student in a school or hostel unless it is on the list. ${ }^{418}$

To ensure complete government control over African education, the act provides that no person shall establish, conduct, or maintain any school for Africans unless it is registered. ${ }^{414}$ Under a 1956 amendment the Minister is empowered to refuse registration or to cancel it substantially at will.115 By virtue of this power control of mission schools is as complete as the government desires. ${ }^{416}$

The government has also put great financial pressure on the private schools. Thus, although the Bantu Education Act provides for subsidies for mission

410. 3 U.N. ComM’N § 166, quoting So. Afr. Gazette, Jan. 21, 1955.

411. H.A. DEB., April 17, 1956, cols. 3751-53. The government may withhold subsidies from a school until a particular individual is dismissed. Ibid.

412. Id., April 24, 1956, col. 4263; Sihlali, Bantu Education and the African Teacher, Africa South, Oct.-Dec. 1956, pp. 49-50.

413. Martin, Battle of the Books, The Forum, Nov. 1957, p. 14, citing Transvaal Educational News, April, 1957, Item No. 21 of Dep't Circ. No. 1 of 1956.

414. Act No. 47 of $1953, \S 9$ (1).

415. Bantu Education Amendment Act, Act No. 36 of 1956, § 3(a), amending $\S 9(\mathrm{k})$ of the principal act (Act No. 47 of 1953); Act No. 36 of 1956, \&3(b), substituting a new $\S 9(2)$ in the principal act. For a discussion of the full significance of the amendments, see H.A. DEB., April 16, 1956, col. 3677.

416. In discussing which schools would be allowed to register, a government representative stated that a prerequisite would be compliance with rules as to: the prescribed syllabus; prohibition of political agitation in the school; the number of children and which children to admit; financial stability; and the demarcation of the area from which the children are drawn. Reasons for refusal to register a school include: failure to comply with conditions in the proper manner; competition with existing or projected community schools; or failure to prove financial stability. H.A. DeB., April 17, 1956, col. 3803; id., April 25, 1956, cols. 4331-32. 
schools upon approval of the Minister, ${ }^{417}$ the subsidies were progressively reduced from $100 \%$ of salaries and allowances to teachers in 1954 to no subsidies at all by 1958.418 At the same time the government prohibited private schools from charging any fees. ${ }^{410}$

The government has, indeed, made no secret of its desire to end mission, particularly Roman Catholic and Anglican, education in the Union. ${ }^{420}$ Under the registration provisions some of South Africa's best known schools have disappeared. ${ }^{421}$ Mission schools which remained open after subsidies ended were held subject to re-registration. ${ }^{422}$ Fifty African mission schools were scheduled to be closed at the end of 1958, and the churches were warned that no private educational institutions would be tolerated which were not situated in African areas or locations. ${ }^{423}$

Reacting as the Nationalists had hoped, most Protestant churches turned their schools over to the government or community. ${ }^{424}$ The Roman Catholic Church and the Seventh Day Adventists, who had never had state subsidies, have continued their schools out of church funds raised within and without the Union; the Anglican church, however, has closed most of its schools rather than give the inferior, segregated education which it feels the current law foists upon Africans. ${ }^{425}$

To make sure that there are no "bootleg" schools for Africans, the Bantu Education Act makes it illegal to operate an unregistered school. ${ }^{426}$ The definition of "Bantu school" is so broad that any class or instruction for more than

417. Act No. 47 of 1953 , § 8(1).

418. Macquarrie, The New Order in Bantu Education, Africa South, Oct.-Dec. 1956, p. 37 ; H.A. DEB., April 18, 1956, col. 3807. In the same debate it was indicated that teachers in such school systems are excluded from the state teachers' pension. Id., June 11, 1956, col. 7791.

419. H.A. DeB., April 17, 1956, col. 3898; id., April 25, 1956, col. 4332. A church school may, however, use funds collected from church members for its support. Id., April 17, 1956, col. 3808.

420. My ancestors were fugitives from the doctrine of that [Roman Catholic] church, and I am not prepared to allow my part of South Africa to develop as it has developed in Johannesburg under people like [Anglican] Father Huddlestone.

H.A. DeB., April 17, 1956, cols. 3777, 3808; id., April 24, 1956, col. 4282.

421. Among those disappearing were Adams High and Industrial School, run by the American Board of Missions for over 100 years; St. Peter's, the "Eton" of South African education; and the Anglican School of Christ the King. Junod, Letter to the Editor, Africa South, Jan.-March, 1957, p. 11. H.A. DeB., March 6, 1956, cols. 1999-2000; id., April 17, 1956, col. 3808.

422. Id., cols. $3777-3808$.

423. 6 Afr. Drg. 64 (1958), citing the Chief Information Officer of the Department of Native Affairs.

424. CarTer 106-07. The reasons included inability to finance the schools as well as a desire to give the new system a chance.

425. Junod, supra note 421; CARTER 107-08.

426. Punishable by a fine of $£ 50$ and six months imprisonment. Act No. 47 of 1953, $\S$ 9(3), as amended by Act 36 of 1956. 
one African child or adult is covered. ${ }^{427}$ Women have been fined for lecturing to children in the fields if a blackboard was available as evidence although no textbooks and only a few slates were used. ${ }^{428}$

The emphasis of the Bantu Education Act is quite naturally placed on primary education, for the number of Africans who advance beyond the lowest levels is pitifully small. In addition, it is clear that the nature of elementary education will necessarily affect the quality and character of secondary education. 429

To follow out its theory of education, the Nationalist government enacted the Extension of University Education Act ${ }^{430}$ in 1959. This act provides for the total segregation of nonwhite from white university students and of various kinds of nonwhite students from each other by the creation of university colleges "for Bantu persons" and "for nonwhite persons other than Bantu persons." 431 Admission to these "ethnic colleges" is to be limited to one or more tribal groups, although the Minister is empowered to make exceptions among the nonwhites. ${ }^{432}$ But no white person may attend any nonwhite university college, ${ }^{433}$ and no nonwhite student not in a university on the act's effective date might thereafter attend any white university. ${ }^{434}$

The rationale of the new university colleges was similar to that which justified the creation of the new Bantu schools:

[U]niversities do not only train professional people. Such a university must also produce individuals who are aware of their mission in life. It

427. Act No. 47 of $1953, \S 1$ (vi).

428. H.A. Deb., April 17, 1956, col. 3790. But see R. v. Tanya, [1957] 2 So. Afr. L.R. 65 (EDL).

429. DAVIE, op. cit. supra note 379.

430. Act No. 45 of 1959. This act is a later, renamed version of the Separate University Education Bill, which was withdrawn until after the 1958 elections assured a continuing Nationalist dominance in Parliament. CARTER 111-12.

431. Act No. 45 of $1959, \S \S 2(1), 3(1)$.

What the hon. Minister seems to overlook is that he is not asking for permission in the Bill to establish university colleges for non-Europeans. He can do that without legislation. What he is seeking to do is to establish by law a prohibition against a Bantu going to any University college other than a Bantu college, a prohibition against a Coloured man going to a college other than ... [one] for Coloured people, and ... an Indian going to any college other than ... [one] for Indians.

H.A. Deb., April 27, 1959, col. 4701.

432. Act No. 45 of $1959, \S 13(5)$.

433. Act No. 45 of $1959, \S 17$.

434. Act No. 45 of $1959, \S \S 31,32$. In response to a question in Parliament, the Minister of Agricultural Economics and Marketing stated that 167 African students were refused admission to Capetown, Witwatersrand, Rhodes and Natal Universities in 1960. Requests were for admission to the faculities of arts, sciences, and medicine, and the refusals were made on the grounds that there were faculties of arts and sciences at the Bantu University Colleges, and a faculty of medicine exists at the Durban medical school for nonwhites. H.A. DEB., March 29, 1960, col. 4291. 
is the specific aim of this Bill not to estrange people from their own national group.

There is a positive need on the part of the non-Whites to have their own institutions ..... Secondly, they must be given the opportunity to develop to the full on the basis of what is peculiarly their own. Thirdly, they must be the bearers of their own culture to stimulate that culture amongst their own national group. Fourthly, the future leaders should be educated and trained there, not to break down the colour bar but to retain it .....435

At the time the act was introduced, there were approximately 26,000 university students in South Africa, of whom about 1,850 were nonwhites. ${ }^{436}$ Of these latter over 400 were at Fort Hare University College, which admitted nonwhites only. The remaining 1,400 , about five percent of the total, were at the "open" universities of Capetown and Witwatersrand (Johannesburg) and at the University of Natal, in segregated classes. ${ }^{437}$ Of the nonwhite university students, 945 , or about half, were Africans. But of that number 499 were taking correspondence courses and 113 were medical students, leaving 333 African undergraduates in regular attendance. ${ }^{438}$

The "separate" universities, then, were created for very small groups of students, whose numbers are not likely to increase as the handicaps implicit in the Bantu Education Act take their toll among potential African college students.

But the small number of students and the restriction of outlook implicit in the "separate" universities are not their only weaknesses. The division of Africans into "tribal" groups, whose members may attend only the college established for their own group, forces many Africans to study far away from home. ${ }^{439}$ Moreover, since the plan is to emphasize instruction in the vernacular

435. H.A. DeB., Apri1 8, 1959, cols. 3171, 3186. Secondarily, it was to prevent the intermixture of nonwhites; thus Indians were accused of "infiltrating" Fort Hare University College and causing it to lose its "distinctive Bantu character"; the students were said to be losing facility in their own language as a result. H.A. DEB., April 22, 1959, col. 4448.

436. Id., April 8, 1959, col. 3211.

437. Ibid. In addition, Rhodes University technically admitted nonwhites to certain graduate courses, but no use was made of these opportunities as a practical matter. CARTER 110 .

The four Afrikaans-speaking universities (Stellenbosch, Pretoria, Bloemfontein, Potchefstroom) always excluded nonwhites from their classes, but the University of South Africa in Pretoria had correspondence courses available to nonwhites, and in 1954 nearly 1,200 were taking such courses. CARTer 110; H.A. DeB., April 10, 1959, col. 3389; Manchester Guardian Weekly, April 28, 1960, p. 5, col. 1.

438. H.A. DeB., April 27, 1959, cols. 4704-05. According to Africa Digest, there was a total of 1,402 nonwhite students attending the "mixed" universitites of Capetown, Witwatersrand, and Natal, and 1,984 more nonwhite students taking correspondence courses. 6 Afr. Dig. 235 (1959). For figures on colored students, see H.A. DEB., April 27, 1959, col. 4754.

439. It is intended that each African shall attend only the college established for his own tribal group. Manchester Guardian Weekly, May 5, 1960, p. 7, cols. 1-3. 
-assuming advanced subjects can be so taught-there is a dismal future for those Africans who do not speak one of the three languages to be used at the new colleges. The same difficulty, exacerbated by the "tribal" character of the entire surroundings as they are being created, faces the large number of ethnically mixed (usually urban) Africans who have lost all tribal associations. ${ }^{400}$ The coloreds, whose usual language is Afrikaans and whose outlook is European, will suffer equally in a "tribal" university created for them. ${ }^{441}$

Another equally great handicap to university education for nonwhites is financial. For the individual students, the inability to obtain scholarships often presents an insuperable barrier to further education. For the more urban and sophisticated coloreds, this is a frequent situation. ${ }^{42}$ But the new tribal universities themselves suffer financially, for the government early made it clear that no additional general funds would be made available for them beyond the $£ 6,500,000$ allotted originally for Bantu primary and secondary education, except as the African community itself would supply them. ${ }^{443}$ As the Minister of Bantu Education explained:

When the Bantu Education Account was first opened, this Parliament accepted the principle that the Bantu Education Account would be opened with an amount equivalent to the requirements of the year in which it was being opened .... The expense connected with any expansion . . . thereafter must be met, not by increasing the amount taken from the Consolidated Revenue Account, but by increasing the Bantu tax portion of the account. After that estimate had been made ... for the first year, it was found that in pegging the amount for that year at $£ 6,500,000$, it was $£ 250,000$ too much ... The following year ... it was $£ 500,000$ more. The effect of that should have been to reduce the amount transferred from the Consolidated Revenue Account to the Bantu Education Account by these amounts. But that was not done in view of the fact that it had already been decided at that time to establish Bantu university institutions sooner or later and to finance them from that account. In the meantime the Bantu have had the benefit of that over-estimate because their taxes were increased at a much later date than would otherwise have been the case. So we are quite justified in meeting the additional cost of the university institutions from the Bantu Education Account . . . 44

However, in 1960 the government went so far as to permit the appropriation of funds for capital expenditures on the Bantu universities, the funds to be repaid

440. H.A. DeB., April 10, 1959, cols. 355-54; id., April 27, 1959, col. 4707. It was suggested that many Africans on the Rand are so mixed tribally that they cannot be classified.

441. H.A. DEB., April 8, 1959, col. 3216.

442. H.A. DEB., April 27, 1959, cols. 4752-53. For the government viewpoint, see $i d$., cols. $4750-51$.

443. Id., col. 4712. The speaker continued at col. 4713 :

$[P]$ rimary and secondary European education for $1954 \ldots$ had something like $£ 30,000,000$ per year spent on it .... [I]n the latest Estimates provision is made for subsidies and assistance to European Universities to the extent of $£ 4,500,000$.

444. Id., col. 4686. 
from the Bantu Education Account "at such times and upon such terms and conditions" as the Minister may decide. ${ }^{445}$

The government has now established, on paper at least, three ethnic colleges for Africans. ${ }^{440}$ The examinations, degrees, diplomas, and certificates are to be those of the University of South Africa until Parliament otherwise provides, 447 and the Minister is authorized to make special arrangements for postgraduate study at a place other than a university college. ${ }^{448}$

But these colleges are completely state dominated. The Minister may, apparently without any hearing, refuse admittance to any student otherwise qualified "if he considers it to be in the interests of the university college to do so." 448 The faculty and staff are entirely subject to executive control as to appointment, promotion, and dismissal. ${ }^{450}$ The traditional "conscience" clause, which the white universities hold one of their dearest privileges, ${ }^{451}$ has been omitted from the statutes establishing the nonwhite university colleges, for as a Nationalist spokesman declared:

[T] he proposed colleges should have a religious basis and . . . a religious character. It is my heartfelt conviction that we cannot for example allow these institutions to be anti-religious or anti-Christ . . . 452

\section{ConcLusions}

This and a previous article have attempted to demonstrate by analyzing major apartheid legislation how South Africa's racial policy is defined and put into operation. It is one of the tragic ironies of the contemporary situation that a theory of separate development is being expanded and implemented in the most highly industrialized country of Africa where economic integration is constantly increasing and is everyday more urgent for continued national pros-

445. Extension of University Education Amendment Act, Act No. 32 of 1960, §§ 1, 2.

446. The University College of Fort Hare in Cape Province for Xhosas; the University College of the North at Turfloop in Pietersburg, Transvaal, for Sotho-speaking people; and the University College of Zululand in Natal Province. 6 Afr. Drg. 234 (1959). University College of Fort Hare Transfer Act, Act No. 64 of 1959; Gov't Notice No. 1195, So. Afr. Gazettc, July 31, 1959, p. 52; Gov't Notice No. 1196, So. Afr. Gazette, July 31, 1959, p. 52.

447. University College of Fort Hare Transfer Act, Act No. 64 of 1959, §§ 20-22.

448. Act No. 64 of $1959, \S 34$.

449. Act No. 64 of 1959, § 16.

450. The basic structure of the university colleges is established in $\$ \S 5-10$, which give complete indirect control to the Minister. Direct power over most personnel is vested in the Minister by $\S \S 25 \& 29$. Cf. Act No. 64 of 1959, $\S \S 6-13,25-27$. Each act creates two councils for each college regulated by it, an all-white council and an (advisory) council of nonwhites. When the Rector of Fort Hare was asked in the spring of 1960 about the part played by the two councils, he replied that they had not yet met. Manchester Guardian Weekly, May 5, 1960, p. 7, col. 2 .

The provisions of the Public Service Act relating to misconduct and inefficient officers apply mutatis mutandis to most (i.e., state post) personnel in the Bantu Universities, Act No. 54 of $1957, \S 30(1)$.

451. H.A. DEB., April 8, 1959, cols. 3193, 3199-3200, 3213-15.

452. Id., col. 3174 . 
perity. ${ }^{453}$ It is equally unfortunate that a forced "back-to-nature" movement, based on an unsophisticated theory of racial differentiation, is being pressed upon the largest group of detribalized westernized nonwhites in sub-Saharan Africa. ${ }^{454}$ The complexity of apartheid legislation can be traced in no small part to the problems of implementing a theory which in no way fits the facts to which it is being applied.

Despite its uncompromising disavowal of twentieth century social philosophy, the Union is under increasing pressure, internal ${ }^{455}$ and external, ${ }^{456}$ to change the basic premises on which its entire political, emotional, and social life has been built. While no one can foretell the future, it would seem likely that coming events will compel a reversal of conduct. This article may suggest how extensive and how complex the process will be, either to pursue further its declared way of life or to reverse the whole trend of its history.

453. Hellmann, Racial Laws versus Economic and Soctac. Factors (1955). But a government spokesman has asked, "What is the good of gaining material riches and prosperity if a nation loses its soul? What good is it if we are prosperous but enrich ourselves at the cost of [black domination over] our children and of future generations?" H.A. DEB., Feb. 1, 1956, col. 832.

454. A prominent South African anthropologist estimated, in conversation with the author, that at least 250,000 Africans have completely absorbed western traditions and culture. Coloreds are almost entirely westernized, even "white," in their ways of life, and Asians are, insofar as government policy permits, becoming typical middle class citizens.

455. Although organized opposition is destroyed whenever possible, recent demonstrations, boycotts of the products of certain Nationalist concerns, and other non-violent activities have not been unnoticed by the authorities.

456. E.g., the recent United Nations resolution calling on UN members to exert pressure on the Union to change its racial policy. A/Res./1598 (XV). A similar resolution was passed by the current General Assembly; the weaker "Indian resolution" was approved, rather than the African-supported one. 


\section{THE YALE LAW JOURNAL}

\begin{tabular}{lll} 
VOLUME 71 & JANUARY 1962 & NUMBER 3 \\
\hline
\end{tabular}

JaN Deutsch

Grorge Lefcoe

James L. Mitchell

CAROL W. TRENCHER

\section{Note \& Comment}

Editors
Alan M. Dershowitz

Editor-in-Chief

David C. Greer

HarRy J. Wexler

Article \& Book

Review Editors

Charles S. Battles, JR. Topics Editor

PhILIP F. Johnson

Manzaging Editor

Sangwoo Ahe

Burton J. Ahrens

LeE Algert

Douglas R. Ayer

Henry G. Bisgater

JOSEPH S. BORUS

Stephen A. Brown

JoHN HART ELY

JOEL J. FINER
AsHLEY L. FoRD

JAMIES O. FREEDMSAN

BRUCE E. FrITCH

JaMres H. GILLESPIE

JoHN P. HeINZ

Algernon S. Holderness, JR.

AlLEN I. IsaAcson

PeTer G. KeLLY

Alan H. Levine
Martin Levine

JoHN T. Marshall

ALAN H. MoLod

THOMAS S. NICHOLS

ALAN R. Novak

Peter G. Platt

Chartes F. Richards, Jr.

SidNey G. SALtz

ROBERT M. SHEPARD

Marie McMahon

Business Secretary

\section{CONTRIBUTORS TO THIS ISSUE}

Ted Finman. A.B. 1950, University of Chicago; LL.B. 1954, Stanford University. Member of California Bar. Assistant Professor of Law, University of New Mexico Law School.

Elizabetr S. Landis. A.B. 1942, Mount Holyoke; M.S. 1943, Syracuse University; LL.B. 1948, Cornell University; Docteur en Droit de l'University de Lyon (France) 1950. Member, New York Bar.

Harvey J. Levin. A.B. 1944, Hamilton College; M.A. 1948, Ph.D. 1953, Columbia University. 